\title{
Research Trends in Career Success: A Bibliometric Review
}

\author{
Roberto Pico-Saltos ${ }^{1,2}$, Paúl Carrión-Mero ${ }^{3, * \mathbb{D}}$, Néstor Montalván-Burbano ${ }^{3,4,5}$ (D) Javier Garzás ${ }^{1}$ and \\ Andrés Redchuk ${ }^{1}$
}

1 Department of Statistics and Operations Research, Rey Juan Carlos University, 28933 Madrid, Spain; vicerrectoradoadministrativo@uteq.edu.ec (R.P.-S.); javier.garzas@urjc.es (J.G.); andres.redchuk@urjc.es (A.R.)

2 Faculty of Engineering Sciences, Quevedo State Technical University, Quevedo 120304, Ecuador

3 Centro de Investigaciones y Proyectos Aplicados a las Ciencias de la Tierra (CIPAT), ESPOL Polytechnic University, Guayaquil 9015863, Ecuador; nmb218@inlumine.ual.es

4 Department of Economy and Business, University of Almería, Citra, Sacramento s/n, La Cañada de San Urbano, 04120 Almería, Spain

5 Innovation, Management, Marketing and Knowledge Economy Research I2Maker, ESPOL Polytechnic University, Guayaquil 9015863, Ecuador

* Correspondence: pcarrion@espol.edu.ec; Tel.: +593-998-265-290

check for updates

Citation: Pico-Saltos, R.; Carrión-Mero, P.; Montalván-

Burbano, N.; Garzás, J.; Redchuk, A.

Research Trends in Career Success: A Bibliometric Review. Sustainability 2021, 13, 4625. https://doi.org/ $10.3390 /$ su13094625

Academic Editors: Gabriela Topa,

Xuesong Zhai and Juan

Carlos Pérez-González

Received: 31 March 2021

Accepted: 16 April 2021

Published: 21 April 2021

Publisher's Note: MDPI stays neutral with regard to jurisdictional claims in published maps and institutional affiliations.

Copyright: (c) 2021 by the authors. Licensee MDPI, Basel, Switzerland. This article is an open access article distributed under the terms and conditions of the Creative Commons Attribution (CC BY) license (https:/ / creativecommons.org/licenses/by/ $4.0 /)$.

\begin{abstract}
The purpose of this article is to provide an overview of academic research on professional success, using the bibliometric analysis to understand the evolution of this field between the years 1990 and 2020. The information was obtained from the publications indexed in the Scopus database, under a rigorous bibliometric process that comprises five parts: (i) criteria search of the field, (ii) selection of database and documents, (iii) inclusion and selection criteria, (iv) software and data selection, and (v) analysis and results. The results show professional success as a scientific discipline in full exponential growth, which allows us to consider the main contributions of authors, institutions, and international contributions, as well as to consider the main themes that have shaped the intellectual structure of the subject through their visualization using bibliometric maps of co-citation and co-occurrence, which combined showed eight main lines of research. The results obtained allowed us to identify patterns of convergence and divergence in various topics, which allows obtaining current and diverse information on the state of the research field's art.
\end{abstract}

Keywords: professional success; objective success factors; subjective success factors

\section{Introduction}

Interest in researching career success has increased in the last 30 years, and this is also due to the increase in the number of graduates from higher education institutions [1]. This is why managers need to maintain a link between the university and their former students since the quality of their training process is related to their success in the labour market [2]. As a result of the monitoring of graduates, experts in the field of education and the labour market indicate that there is a considerable percentage of students who are not working in their specialties, which translates into job dissatisfaction [3].

Professional success starts from the etymological meaning of the word "success", which comes from the Latin "exitus" which means exit, a final and satisfactory result of a task [4]. Professional success is known as the accumulated positive achievements of people, real and perceived, as a result of their work experiences [5-8]. This definition shows the need to divide the analysis of success into extrinsic or objective components [8-10] and intrinsic or subjective of the individual $[6,11,12]$. Objective career success is evaluated in terms of salary and promotions [12]; while subjective success refers to the evaluation of the individual's own criteria on the progress of the career [13]. To achieve success, a balance of four dimensions is necessary: personal, professional, business, and family [14].

In this field of study, the factors that influence professional success have been related [15]. Objective factors include good salary [16], age [17], labour promotion [18], 
recognition [19], work in a prestigious company, leadership [20], and teamwork [21]. On the other hand, the main subjective factors are the following: achieving happiness [22], gender [23], professional and job satisfaction [24], emotional intelligence [25], fulfilment of goals [5], and ethical behaviour [26]. These factors are the main variables attributed to professional success and have been studied throughout the literature $[7,27,28]$.

Professional success is related to various areas of knowledge, including the influence of gender. When competing with men in the chosen field of training, the professional problems faced by women were analysed while still fulfilling the main role of mother and wife [29]. Successful women serving as corporate directors in Canadian companies are recognized due to their high level of training, entrepreneurial experience, and having reached a high occupational level [30].

Additionally, it is recognized that self-confidence, good communication skills, and academic improvement courses are the most important factors for success and professional advancement [31]. Good command of communication is essential for achieving the personal and professional success of students in the future [32]. In a study aimed at professionals in business, informatics, and engineering, attached to the Master's in Information Systems (MIS), of the University of the State of California, it is showed that professional success does not depend exclusively on technical skills in computer science but also communication and interpersonal skills [33].

In the industrial sector, graduates of engineering programs who achieve professional success possess effective communication and information skills [34]. In industrial health management, the factors that increase economic income do not affect life satisfaction. The only predictor of satisfaction is feeling safe while working outside of their home organizations [35].

The field of medicine shows that medical teachers who dedicate more than $50 \%$ of their time to clinical care have less time in tutoring. This contributes to notable differences in the promotion and greater dissatisfaction with academic medicine [36]. Mentoring is considered a key factor in professional development, and it has been shown that people who have received tutoring present greater opportunities for promotion, higher salary, and professional satisfaction [37].

On the other hand, intelligence quotient (IQ) and, consequently, high undergraduate grades influence the rate of increase in income over the long term and do not influence the starting salary [38]. Human resource development needs to apply new means to assess professional development. Therefore, both objective and subjective factors must be included because traditional assessment methods are inadequate for capturing change and progress [39]. Finally, previous undergraduate internships' participation generates advantages in early career success, which includes: less time to obtain the first position, higher salary, and general job satisfaction [40].

Research in the field of career success has been strengthened in recent years. However, a global analysis of the issue has not been carried out. Bibliometric studies are a recently used research tool for analysing scientific activity in a specific field of study [41,42]. The bibliometric analysis allows one to quantitatively evaluate the impact of the research, recognizing past particularities and critical points in the present, in order to suggest research trends [43].

Thus, in this field of study on professional success, the following research questions arose: (1) What are the trends in professional success? (2) Which authors had the greatest impact in the field of professional success? and (3) What is the intellectual structure of this professional success knowledge base?

This study aims to carry out a bibliometric analysis by collecting information from the Scopus database to understand the intellectual structure and trends on professional success.

This article is made up of four main sections: First, following the introduction, the materials and methods section are presented, which describes the database used, as well as the search predictors used. The second section describes the research's outstanding results, showing the trends and new research lines. Third, there is the discussion, where 
the main relationships between the different results presented are summarized. Finally, the fourth section includes the conclusions of the investigation. It is worth mentioning that supplementary material is added where secondary tables are included. Finally, a section of the references used in this research is added.

\section{Materials and Methods}

Analysing an academic field requires meticulous work on the researcher's part, allowing the researcher to deepen and increase knowledge. This is achieved by using a rigorous and formal procedure that allows the process to be reproduced and made transparent, called a systematic review of the literature $[44,45]$. This rigorous process is characteristic of bibliometric analyses [46,47].

Bibliometrics is considered a research field, which allows analysing scientific production and its performance according to its authors, countries, institutions, and journals [48-50]. That is, it allows for the studying of the structure of an academic discipline or area of knowledge [51]. These analyses are complemented with visualization maps, called bibliometric maps or scientific maps, allowing one to observe the structures and their connections of the various investigations, disciplines, and research fields [52,53].

These bibliometric studies have allowed the study in various fields of knowledge such as business and management [54-56], education [57,58], geoscience [59,60].

In this study, a systematic process was established (see Figure 1): (i) criteria search of the field, (ii) selection of database and documents, (iii) inclusion and selection criteria, (iv) software and data selection, and (v) analysis and results.
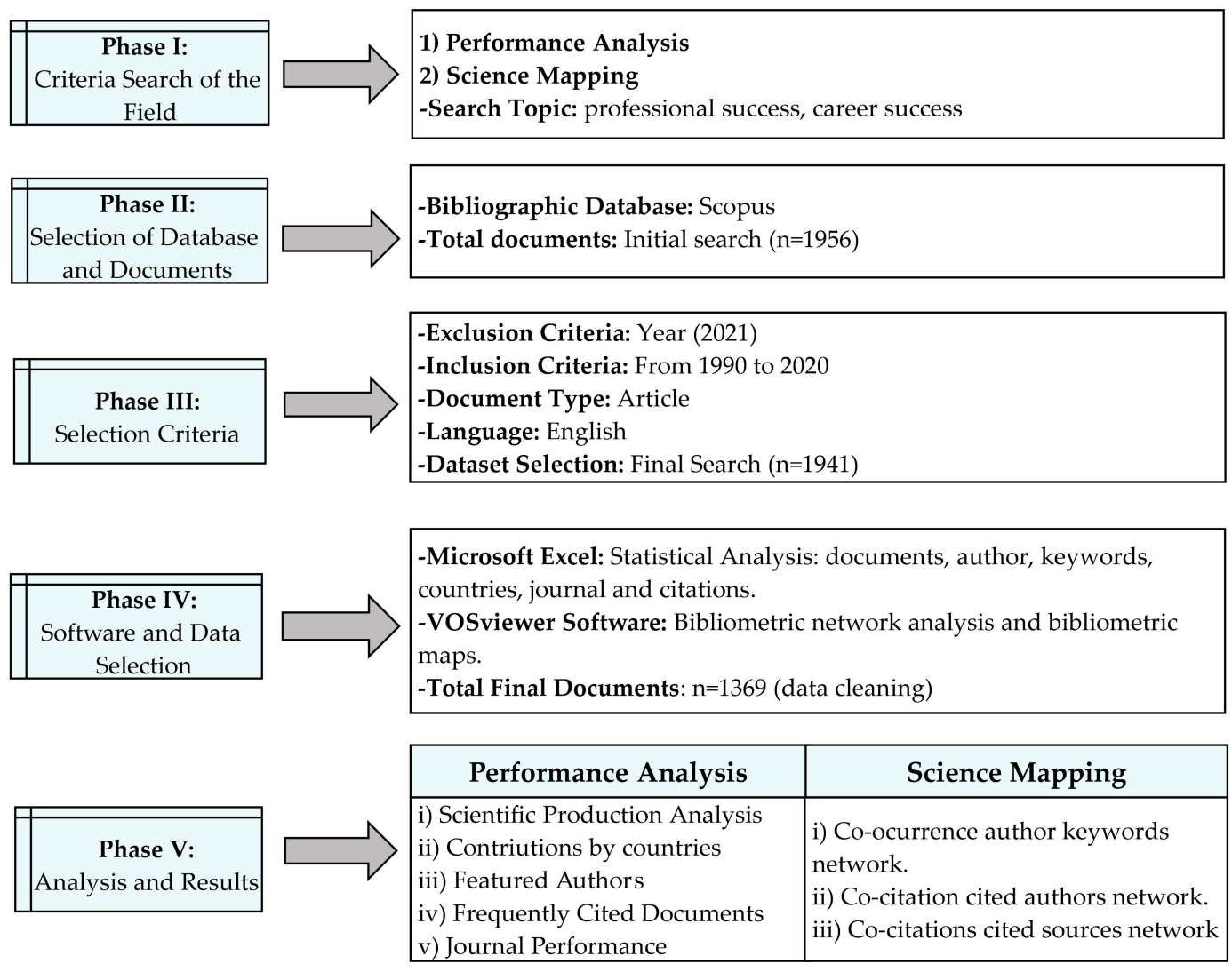

Figure 1. Methodological Scheme

\subsection{Criteria Search of the Field}

This research seeks to assess the conceptual evolution of the research topic through a combination of two approaches: (i) performance analysis and (ii) science mapping [52]. The 
first, performance analysis, allows one to evaluate the impact of publications by contrasting information that relates these documents to related authors, countries, and institutions. The second approach is bibliometric mapping, also called science mapping, which is a graphic representation that allows for the visualizing and identifying of the structure of the field of study and its relationships with the main research topics [52,60].

These analyses require identifying the field of study; therefore, it is necessary to use descriptors that allow it to be limited. For this purpose, the terms used were "professional success" [61,62] and "career success" $[63,64]$, which have been used interchangeably by researchers in this area.

\subsection{Selection of Database and Documents}

In bibliometric studies, it is necessary to use a source or database that is reliable and of quality to proceed to extract the required information. The Scopus database is selected due to its (i) wide coverage of journals in most fields of knowledge; (ii) high-quality standards (for example, indicators such as Scimago Journal Rank); (iii) tools for data visualization and analysis; and (iv) easy access to your references [65-67].

The data were extracted from the Scopus database in January 2021, using the mentioned descriptors and a combination of widely accepted variables in bibliometrics related to "titles, abstract, and keywords", allowing one to obtain the following topic search: $(T S)=($ TITLE-ABS-KEY ("Professional success") OR TITLE-ABS-KEY ("career success")) In the initial search, 2937 documents were obtained.

\subsection{Selection Criteria}

In this third phase, criteria were established which made it possible to refine the information obtained, the documents published between the years 1991-2020 were considered in order to analyse the intellectual structure of the field of study of the last three decades, and 2021 was excluded because it was the year in course. It was limited to scientific articles since they are considered the most representative of scientific activity due to their visibility, impact, and knowledge certified by blind peers [68,69], and 1956 articles were obtained from this restriction.

The data obtained from Scopus were downloaded in CSV format (comma-separated values), displaying information on the scientific production of the field of study, such as the authors and their affiliations, title and year of publication, keywords, and abstract, among others, which are considered relevant. This bibliographic information must be reviewed and refined, eliminating duplicate files or errors in the records [70], and 15 articles were discarded among erroneous and duplicate documents; that is, a base of 1941 articles was obtained.

Additionally, a manual analysis of the selection of articles was carried out by the authors. This selection made it possible to obtain an inclusion criterion for articles that meet a definition of professional success proposed by the author Judge [64] "The real or perceived achievements that people have accumulated as a result of their work experiences." The authors made this selection, who independently carried out the manual refinement of the documents, a procedure that ensures the quality of the information by reducing outliers [53,71]. As a result, a database of 1369 articles was obtained related to the study topic; that is, the 572 articles that did not meet the established definition and scope of the study were eliminated.

\subsection{Software and Data Selection}

Next, we proceed to the selection of the software to be used based on the data selection. Excel software has been used for data cleaning and performance analysis corresponding to the results section [72]. About the analysis of the structure of the field of study, bibliometric maps were constructed using the VOSviewer software, version 1.6.16 (University of Leiden-Netherlands), which allows for the formation and visualization of a bibliographic 
network, using graphs of two dimensions [73]. This software has been used in other studies in various areas of knowledge [74-77].

\subsection{Analysis and Results}

Data analysis is done in two stages. The first is a statistical analysis of the data, which allows for the performance analysis of the intellectual structure, considering the growth patterns of publications and the contributions made by the main countries, universities and authors, and the renowned journals in the field of study [52]. The second corresponds to the analysis of the intellectual structure through the construction of bibliometric maps. The cooccurrences of author and co-citation words (authors and journals) are examined, allowing for a broad understanding of the structure to be obtained for the field of study $[55,78,79]$.

\section{Results}

\subsection{Performance Analysis}

\subsubsection{Scientific Production Analysis}

A total of 1369 scientific articles, indexed in Scopus, reveal a constant growth in the last three decades (1991-2020), showing a growing interest in the academy's part (see Figure 2). For analysis purposes, it was divided into three time periods: introduction (1991-2000), growth (2001-2010), and maturity (2011-2020).

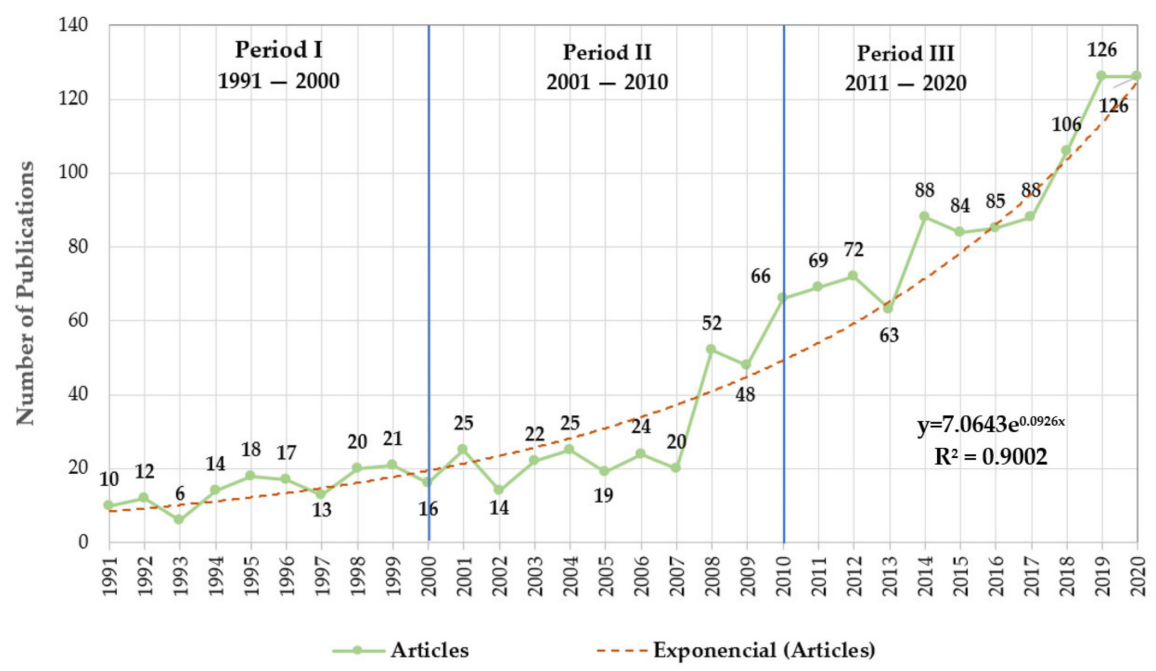

Figure 2. Growth of scientific production relating to professional success.

Period I-Introduction (1991-2000): During this period, 147 articles were published, representing $10.74 \%$ of all publications on this subject, with 8196 citations. Some initial research focused on professional success and gender relations, analysing from the professional trajectory [80], cognitive ability [81], and social and personal attributes [82], as well as work style and job satisfaction [24]. Later studies continued the study of professional success from an individual approach with the organization, examining human capital $[83,84]$, personality [8,64], individual, family and organizational differences [11], and motivational variables [85]. Other studies propose political influence [7], being protected or having a mentor [86], social achievements [19], or rewards related to job promotion and salary increases [27]. Finally, studies related to subjectivity-objectivity [4,87], objective (extrinsic), and subjective (intrinsic) success [8,64] were developed.

Period II-Growth (2001-2010): Greater development of the study field is exhibited, with 315 documents (23.01\%), allowing 17,529 citations to be obtained. In this period, investigations were carried out that were related to professional success with personality [5,87-89], employability of the professional [90,91], and job or professional assistance networks $[92,93]$. Other authors considered some influences that can modify professional 
success when examining the value of mentoring and the actions of mentors [94-96] professional self-efficacy [97], professional attitude [98], the value of work [99], or ethical behaviour [26]. Situations related to the individual as a professional are also examined, considering happiness [100] or physical stature [101].

Period III-Maturation (2011-2020): A significant increase in the number of publications is observed, from 315 in period II to 907 publications in this period, representing $66.25 \%$ of the total number of publications and 11,530 citations. During this period, studies were developed that relate professional success to work activity, considering employability [102], professional adaptability as a psychosocial resource [103-105], flexibles professional practices [106], or vocation and labour commitment [107]. Other researchers studied the relationship between professional success in the individual through their personality roles [108], narcissism [109], dispositional positive affect [110], their behaviour in professional networks [111], gender [23], or their culture of origin and place of reception [61]. Some variables related to the individual's career were also considered, such as factors of professional success, investigating mobility and employability [112], the perception of career management [113], career advancement [18], or the impact of a tutor on their work activities $[114,115]$. In recent years, it has been considered to study professional shocks as unexpected events in the professional career [116], the genetics of the individual linked to their education [117], creative cognition [118], the impact of international work experience [119], or happiness, considering that they can receive higher income and exhibit better performance [22]. Other studies looked at subjective career success through professional proactivity [120] and leadership [20].

Additionally, Price's law has been used for the productivity analysis of a field of study [121-123], which determined that it fits an exponential growth model $\left(y=7.0643 \mathrm{e}^{0.0926 x}\right)$ where the value of $R^{2}=0.9002$ (see Figure 2).

\subsubsection{Contributions by Countries}

The contribution of the different countries was established considering the affiliation of the authors of the articles. The results show the collaboration of 76 countries. Table 1 shows the 15 main countries that have contributed to this field of study, from Europe (8), Asia (4), America (2), and Oceania (1).

The United States leads the ranking of the most influential countries with 603 documents and 23,628 citations. This is due to the importance that the field of study has generated in recent years when considering labour resources and their demands related to personal satisfaction and professional success [124]. The second-place corresponds to the United Kingdom with 133 documents and 3915 citations. The third and fourth places correspond to Canada and Germany, respectively. Belgium has the highest average citations (45.20) of the group.

Table 1. Top 15 countries by the number of articles.

\begin{tabular}{ccccc}
\hline Ranking & Country & Documents & Citations & Average Citations \\
\hline 1 & United States & 601 & 23,689 & 229,691 \\
2 & United Kingdom & 133 & 3915 & 101,569 \\
3 & Canada & 93 & 1609 & 58,473 \\
4 & Germany & 87 & 2462 & 89,419 \\
5 & Australia & 75 & 1421 & 45,053 \\
6 & Netherlands & 61 & 2267 & 66,417 \\
7 & China & 58 & 701 & 33,785 \\
8 & Spain & 36 & 367 & 31,396 \\
9 & Switzerland & 36 & 822 & 47,363 \\
10 & France & 35 & 789 & 36,997 \\
11 & Malaysia & 29 & 219 & 33,891 \\
12 & South Korea & 28 & 188 & 43,236 \\
13 & Belgium & 25 & 1130 & 27,398 \\
14 & Hong Kong & 21 & 786 & 28,852 \\
15 & Italy & 21 & 172 &
\end{tabular}


This cooperation between countries needs to be analysed using science maps. For this purpose, the VOSviewer software was used, identifying those who have made at least five contributions to professional success. Figure 3 shows the bibliographic coupling analysis of countries, exhibiting 38 nodes (countries) in six clusters and maintaining 688 links of relationships. The strength of cooperation can be seen in the width of the links. The United States is the central nucleus, presenting 37 collaborative relationships (links), with greater intensity than Germany, Canada, France, the United Kingdom, and Australia. Whereas the United Kingdom frequently collaborates with the United States, China, and Canada. Countries with a reduced number of collaborations, such as Nigeria, Argentina, and Brazil, are shown.

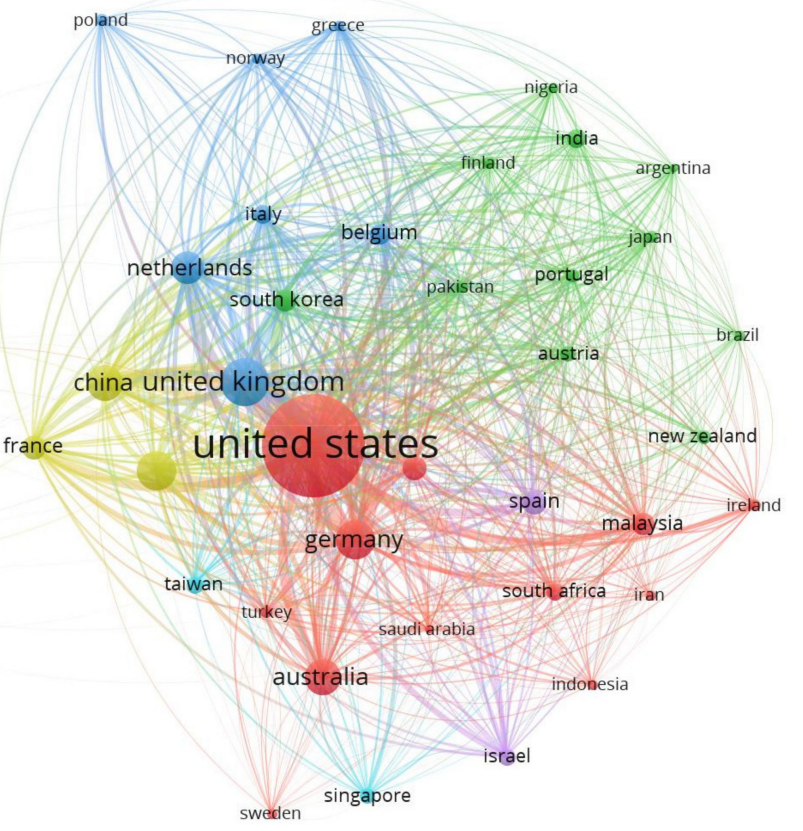

Figure 3. Bibliographic coupling of countries.

Next, Figure 4 shows a map that includes the 76 countries contributing to the study topic. The 15 most prominent countries are distinguished by colours and number of publications. Countries that have not posted about career success are shown in white.

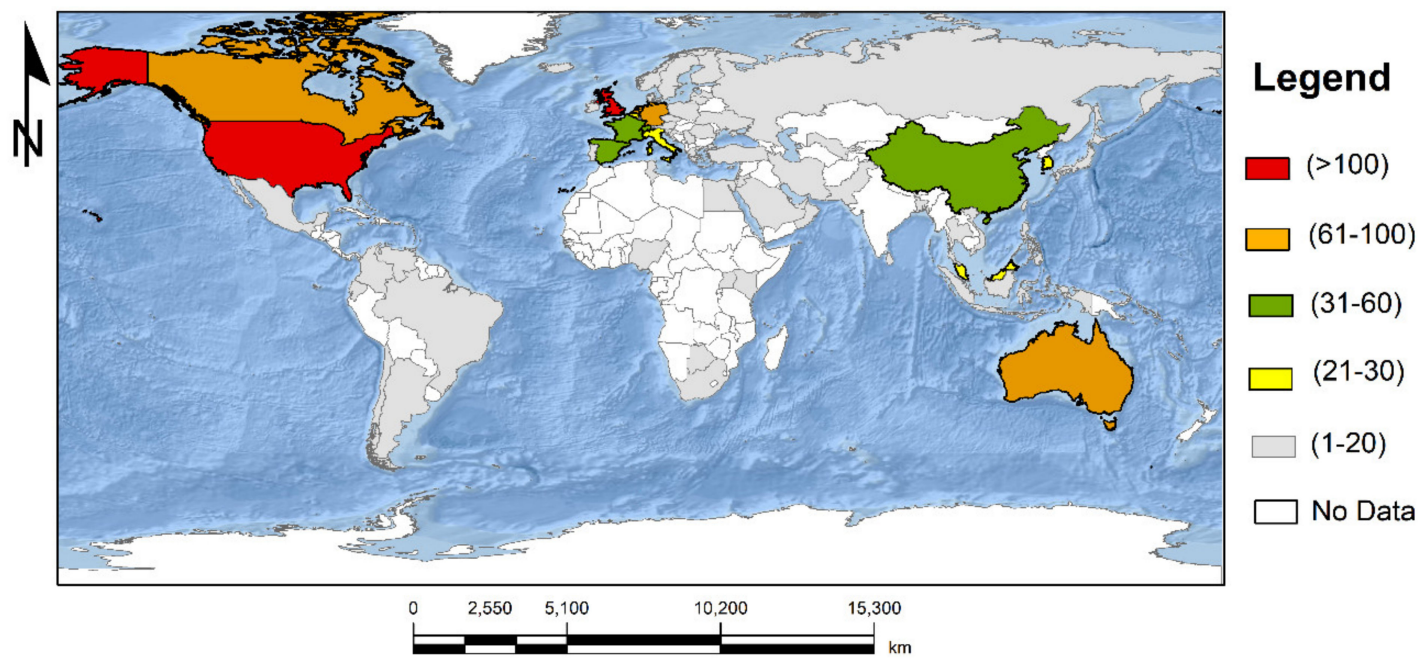

Figure 4. Main contributing countries map in career success. 


\subsubsection{Featured Authors}

In the professional success study, the 1369 articles have been written by 3106 authors. Authors who mostly present a single publication $(87.99 \%)$, two publications $(8.15 \%)$, three publications $(1.74 \%)$, and four or more $(2.12 \%)$. In Table 2 , the three authors with the highest production are shown, Judge T.A. (3837 citations), Kraimer M.L. (3478 citations), and Seibert S.E. (3016 citations). These authors belong to the United States.

Four works are highlighted in the top 15 of most cited documents (see Table 3) and published in the journals Personnel Psychology, Journal of Applied Psychology, and Journal of Vocational Behavior. The most representative author is Timothy A. Judge, from Fisher College of Business (United States), with 14 articles. The second author with the highest number of publications is Daniel M. Spurk from the University of Bern (Switzerland), where his representative works have been carried out with Andrea E. Abele, from the Friedrich-Alexander-Universität Erlangen-Nürnberg [97,125-128].

Table 2. Top 15 most cited authors.

\begin{tabular}{|c|c|c|c|c|c|}
\hline Author & Institution & Country & Documents & Citations & H-Index \\
\hline Judge T.A. & Fisher College of Business & United States & 14 & 3837 & 89 \\
\hline Spurk D. & University of Bern & Switzerland & 14 & 695 & 19 \\
\hline Zhou W. & Renmin University of China & China & 12 & 241 & 10 \\
\hline Baruch Y. & Southampton Business School & United Kingdom & 11 & 330 & 42 \\
\hline Burke R.J. & $\begin{array}{l}\text { Schulich School of Business } \\
\text { Friedrich-Alexander- }\end{array}$ & Canada & 11 & 165 & 53 \\
\hline Abele A.E. & $\begin{array}{c}\text { Universität } \\
\text { Erlangen-Nürnberg }\end{array}$ & Germany & 10 & 650 & 32 \\
\hline Bozionelos N. & Emlyon Business School & France & 10 & 502 & 22 \\
\hline Hirschi A. & University of Bern & Switzerland & 10 & 241 & 29 \\
\hline Blickle G. & Universität Bonn & Germany & 9 & 207 & 21 \\
\hline $\begin{array}{l}\text { Van Der Heijden } \\
\text { B.I.J.M. }\end{array}$ & Universiteit Gent & Belgium & 9 & 861 & 40 \\
\hline Buddeberg-Fischer B. & $\begin{array}{l}\text { Rehabilitation Clinic } \\
\text { Seewis (GR) }\end{array}$ & Switzerland & 8 & 339 & 25 \\
\hline Kraimer M.L. & $\begin{array}{c}\text { Rutgers University-New } \\
\text { Brunswick }\end{array}$ & United States & 8 & 3478 & 30 \\
\hline Orpen C. & The Business School at BU & United Kingdom & 8 & 206 & 20 \\
\hline Otto K. & Philipps-Universität Marburg, & Germany & 7 & 49 & 14 \\
\hline Seibert S.E. & $\begin{array}{c}\text { Rutgers University-New } \\
\text { Brunswick }\end{array}$ & United States & 6 & 3016 & 21 \\
\hline
\end{tabular}

\subsubsection{Frequently Cited Documents}

To assess a field of study, it is necessary to consider documents based on the citations obtained [122]. The scientific production of professional success (1369 articles) presents 37,255 citations. Table 3 shows the publications which are part of the 15 most cited documents on professional success and represent $1.09 \%$ of the total.

The article with the highest number of citations is published by Seibert S.E., Kraimer M.L., and Liden R.C. in 2001 in the Academy of Management Journal. 
Table 3. Top 15 most cited documents on the subject of career success.

\begin{tabular}{|c|c|c|c|c|c|}
\hline $\mathbf{R}$ & Authors & Year & Article Title & Citations & References \\
\hline 1 & $\begin{array}{l}\text { Seibert S.E., Kraimer } \\
\text { M.L., Liden R.C. }\end{array}$ & 2001 & A social capital theory of career success & 1221 & [63] \\
\hline 2 & $\begin{array}{l}\text { Judge T.A., Higgins } \\
\text { C.A., Thoresen C.J., } \\
\text { Barrick M.R. }\end{array}$ & 1999 & $\begin{array}{l}\text { The big five personality traits, general } \\
\text { mental ability, and career success across the } \\
\text { life span }\end{array}$ & 1062 & [64] \\
\hline 3 & $\begin{array}{c}\text { Judge T.A., Cable D.M., } \\
\text { Boudreau J.W., Bretz } \\
\text { R.D., Jr. }\end{array}$ & 1995 & $\begin{array}{l}\text { An Empirical Investigation of the } \\
\text { Predictors of Executive Career Success }\end{array}$ & 766 & [83] \\
\hline 4 & $\begin{array}{l}\text { Seibert S.E., Kraimer } \\
\text { M.L., Crant J.M. }\end{array}$ & 2001 & $\begin{array}{l}\text { What do proactive people do? A } \\
\text { longitudinal model linking proactive } \\
\text { personality and career success }\end{array}$ & 738 & [87] \\
\hline 5 & $\begin{array}{l}\text { Seibert S.E., Grant J.M., } \\
\text { Kraimer M.L. }\end{array}$ & 1999 & Proactive personality and career success & 723 & [8] \\
\hline 6 & $\begin{array}{l}\text { Nosek B.A., Spies J.R., } \\
\text { Motyl M. }\end{array}$ & 2012 & $\begin{array}{c}\text { Scientific Utopia: II. Restructuring } \\
\text { Incentives and Practices to Promote Truth } \\
\text { Over Publishability }\end{array}$ & 552 & [129] \\
\hline 7 & $\begin{array}{l}\text { Van Der Heijde C.M., } \\
\text { Van Der Heijden B.I.J.M. }\end{array}$ & 2006 & $\begin{array}{l}\text { A competence-based and } \\
\text { multidimensional operationalization and } \\
\text { measurement of employability }\end{array}$ & 450 & [90] \\
\hline 8 & $\begin{array}{l}\text { Parasuraman S., Purohit } \\
\text { Y.S., Godshalk V.M., } \\
\text { Beutell N.J. }\end{array}$ & 1996 & $\begin{array}{c}\text { Work and family variables, entrepreneurial } \\
\text { career success, and } \\
\text { psychological well-being }\end{array}$ & 438 & [130] \\
\hline 9 & $\begin{array}{l}\text { Eby L.T., Butts M., } \\
\text { Lockwood A. }\end{array}$ & 2003 & $\begin{array}{c}\text { Predictors of success in the era of the } \\
\text { boundaryless career }\end{array}$ & 436 & [131] \\
\hline 10 & Judge T.A., Cable D.M. & 2004 & $\begin{array}{c}\text { The effect of physical height on workplace } \\
\text { success and income: Preliminary test of a } \\
\text { theoretical model }\end{array}$ & 398 & [101] \\
\hline 11 & Bretz R.D., Judge T.A. & 1994 & $\begin{array}{l}\text { Person-organization fit and the theory of } \\
\text { work adjustment: Implications for } \\
\text { satisfaction, tenure, and career success }\end{array}$ & 369 & [132] \\
\hline 12 & Fuller Jr. B., Marler L.E. & 2009 & $\begin{array}{c}\text { Change driven by nature: A meta-analytic } \\
\text { review of the proactive } \\
\text { personality literature }\end{array}$ & 332 & [88] \\
\hline 13 & Spangler W.D. & 1992 & $\begin{array}{c}\text { Validity of questionnaire and TAT } \\
\text { measures of need for achievement: Two } \\
\text { meta-analyses }\end{array}$ & 327 & [19] \\
\hline 14 & $\begin{array}{l}\text { Seibert S.E., } \\
\text { Kraimer M.L. }\end{array}$ & 2001 & $\begin{array}{c}\text { The Five-Factor Model of Personality and } \\
\text { Career Success }\end{array}$ & 322 & [5] \\
\hline 15 & Rothwell A., Arnold J. & 2007 & $\begin{array}{l}\text { Self-perceived employability: } \\
\text { Development and validation of a scale }\end{array}$ & 310 & [91] \\
\hline
\end{tabular}

R: Ranking.

This study shows that social resources positively affect professional success, based on three main advantages offered by the network: career sponsorship and access to information and resources [63]. Followed by the article published in 1999 in the journal Personnel Psychology, in this article, the relationship of the personality model traits, based on five factors and mental faculty, with professional success, was analysed [64]. Finally, the third most cited article was the one published in 1995, in the journal Personnel Psychology by Judge et al. [83], where it was already considered that certain variables intervene in professional success, both objective (salary and ancestry) and subjective (job satisfaction and professional satisfaction). Other articles that have generated more than 300 citations are displayed in the table in question.

\subsubsection{Journal Performance}

This analysis allows an overview of the field of study to be obtained by knowing the journals in which the various documents and fields of knowledge have been published [50]. 
The subject of professional success has been considered by 691 journals, where the 15 most important ones represent $25.64 \%$ of the scientific production and have $50.49 \%$ of the citations. Table 4 shows the 15 most important journals based on the number of publications, along with performance indicators: Citescore, Scimago journal rank (SJR), and source-normalized impact per paper (SNIP).

Table 4. Top 15 most cited journals on the research field.

\begin{tabular}{|c|c|c|c|c|c|c|}
\hline Journals & Articles & Citations & Citescore & SJR & SNIP & H-Index \\
\hline Journal of Vocational Behavior & 90 & 7103 & 6.3 & 2.210 & 2.551 & 141 \\
\hline Career Development International & 80 & 1763 & 3.6 & 1.052 & 1.600 & 56 \\
\hline International Journal of Human Resource Management & 34 & 822 & 5.5 & 1.263 & 1.885 & 107 \\
\hline Journal of Career Development & 27 & 504 & 3.1 & 0.564 & 1.356 & 41 \\
\hline Journal of Career Assessment & 14 & 349 & 4.1 & 1.119 & 1.694 & 56 \\
\hline Frontiers in Psychology & 12 & 62 & 3.2 & 0.914 & 1.200 & 95 \\
\hline Human Resource Management & 11 & 658 & 8.5 & 2.322 & 3.094 & 87 \\
\hline Journal of Applied Psychology & 11 & 2030 & 10.7 & 6.423 & 3.692 & 269 \\
\hline Journal of Occupational and Organizational Psychology & 11 & 611 & 5.1 & 1.774 & 2.092 & 106 \\
\hline Journal of Managerial Psychology & 11 & 428 & 3.9 & 1.046 & 1.542 & 74 \\
\hline Journal of Organizational Behavior & 11 & 1132 & 9.7 & 3.606 & 3.273 & 164 \\
\hline Human Relations & 10 & 300 & 7.1 & 2.519 & 3.043 & 124 \\
\hline Journal of Management Development & 10 & 194 & 3.2 & 0.516 & 1.207 & 55 \\
\hline Personnel Psychology & 10 & 2968 & 2 & 0.351 & 0.597 & 133 \\
\hline Personnel Review & 9 & 417 & 3 & 0.841 & 1.458 & 67 \\
\hline
\end{tabular}

The most important journal based on its production is the Journal of Vocational Behavior (90 publications), whose research areas are career choice, professional development, and career adjustments throughout professional life. The second and third places are occupied by Career Development International (80) and International Journal of Human Resource Management (34). Based on its citations, the Journal of Vocational Behavior is the most cited (7103), followed by the Journals Personnel Psychology (2968) and Journal of Applied Psychology (2030). Based on CiteScore's performance indicators, the most prominent journal in the Journal of Applied Psychology (10.7) has the highest H-Index (269). Followed by the Journal of Organizational Behavior with 9.7 from Citescore and 164 from H-Index. Regarding the prestige of the journals (SJR), the most important is the Journal of Applied Psychology, Journal of Organizational Behavior, and Human Relations.

\subsection{Science Mapping}

\subsubsection{Co-occurrence Network of Author Keywords}

This bibliometric analysis represents the connection between the keywords, forming a network where those that appear more frequently in the study subject are indicated, thus allowing one to examine concepts (keywords) and themes (grouped concepts in clusters). This analysis was run with the VOSviewer software, which generates a visual and multidimensional representation of the data $[59,133]$.

A total of 2777 keywords were obtained from the database, of which 116 remained in the documents with an occurrence of at least five times. These various topics were divided into 10 groups (see Table S1 in the Supplementary Materials section). Figure 5 represents these eight groups, with 92 nodes, 675 links, and a total link strength of 1290. The term "career success" has 276 occurrences and a relationship with 71 terms; it is in Group 3 (blue colour) as the most relevant word. 


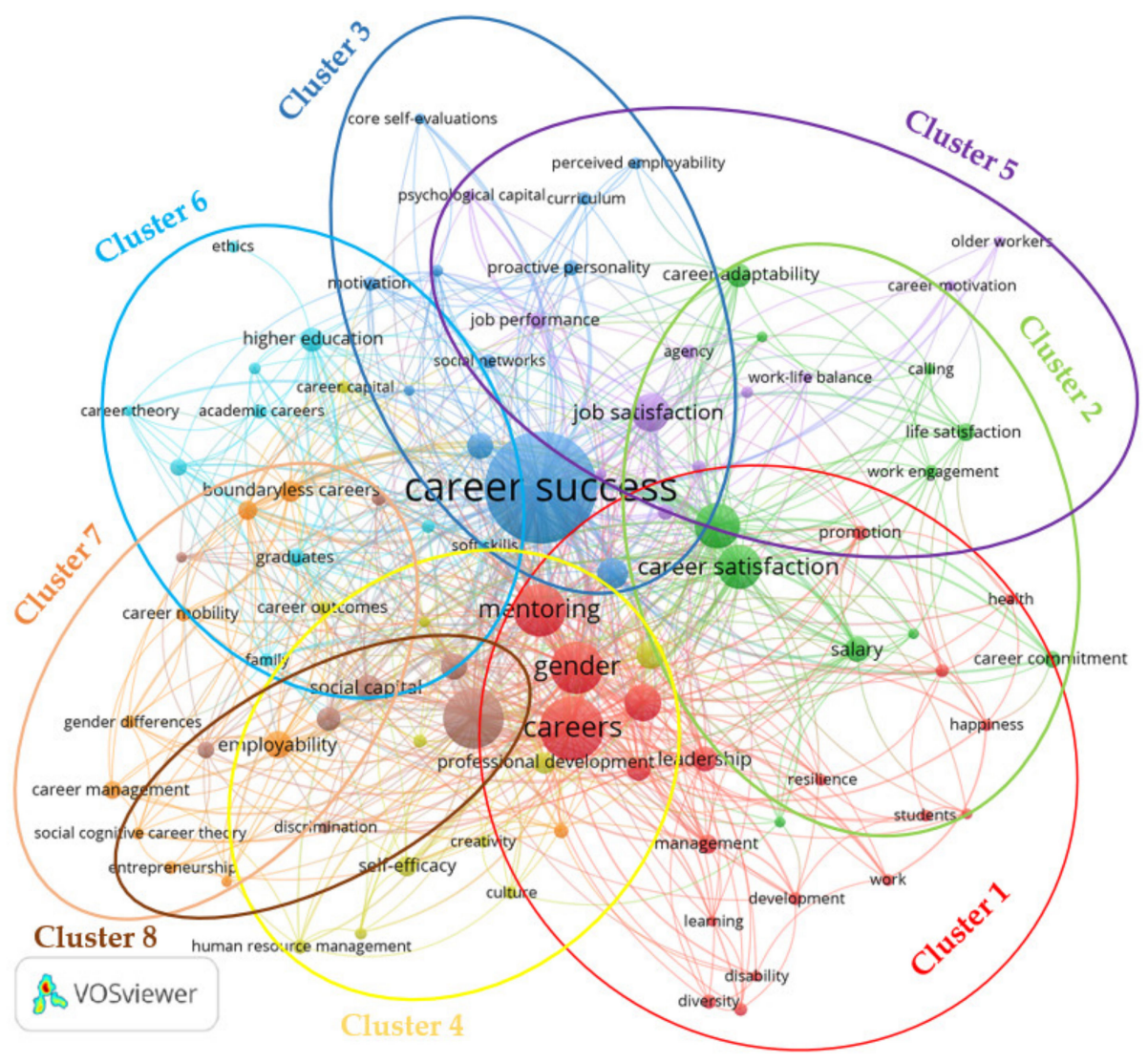

Figure 5. Co-occurrence network of author keywords.

According to the number of nodes (20), the most extensive research area is cluster 1, coloured red, as shown in Figure 5. This class is called: 'Career and Gender', since the two terms of the highest co-occurrences are career and gender, with 108 and 76 co-occurrences. In this area, authors such as Sosik study the relationships between orientation to learning goals, transformational leadership, and professional success expectations [134]. Much of the choice of occupation is attributed to the types of occupations considered suitable for men and women [135].

Otherwise, it seeks to generate information about the factors that influence women's disadvantageous workplace position [136]. Currently, according to Jang studies, gender measured the link between domestic office chores and promotion in such a way that the relationship was statistically revealing for men but not for women [137]. From the evaluation of the relationship between having a mentor and objective professional results, having a mentor is associated with better professional advancement results [133]. Mentoring is a professional partnership between a mentor who cooperates with her professional experience with an apprentice to train him with similar problems [138].

According to the number of nodes (11), the second most extensive research area is cluster 2, coloured green: 'Objective and Subjective Career Success'. Currently, there is a difference between objective and subjective professional success; external persons value the former according to the level of work, income, status, salary, and occupation [139]. On the other hand, subjective career success is a subjective construct that interprets individual employees' success. It was evidenced that the person-work adjustment intervenes in the relationship between perceived professional support and subjective professional success [140]. In recent years, the effects of emotional and social competencies on the boundless career and objective career success have been investigated [141].

The third research area is cluster 3, with 13 nodes (blue), as shown in Figure 5. This cluster is called 'Career Success', since this term has 276 occurrences and is led by the authors Seibert S.E., with 1221 citations [63], Judge T.A. with 1062 citations [64], Nosek B.A, 
with 552 citations [129], and Van Der Heijde C.M. with 450 citations [90], which shows a growing interest in this line of research. The authors of this group have provided several studies, such as Parasuraman, which analyses work and family variables involved in career success and psychological well-being [130]. On the other hand, the theory of labour adjustment is explored, showing the relationship between person-organization adequacy and professional success [132].

Cluster 4 (yellow), made up of 11 nodes, represents the fourth research area, 'Emotional Intelligence' since this term is the one with the highest co-occurrence in this cluster (27). Regarding emotional intelligence, it is considered one of the main qualifiers for professional success [142]. Likewise, a high degree of emotional intelligence indicates a high business potential, which leads to greater professional success [143]. It examines three professional competencies (perceived job satisfaction, perceived internal marketability, and perceived external marketability), recognized as predictors of success in the borderless career [131] and has 436 citations. Subsequently, the relationship between structural empowerment, innovative behaviour, self-efficacy, and professional success is proposed [144].

The fifth research area is cluster 5 (purple), made up of 11 nodes called 'Job Satisfaction'. In this cluster, in Drewery's research, objective and subjective indicators are attributed to professional success; within the subjective ones, job satisfaction is included [145]. Likewise, wellbeing, life goals, and values must be considered to achieve job satisfaction [146]. On the other hand, human resources are essential to identify the factors that affect job performance [147]. Finally, the attribution of the perception of evaluation centre workers regarding their job satisfaction and organizational commitment is investigated, which is one of the key elements for predicting work behaviour [148].

Cluster 6 (light blue) represents the sixth research area, made up of 10 nodes, and is called: 'Higher Education' because it is the term with the highest occurrence (20) in this class. According to Ummatqul, higher education graduates require managing, in addition to professional skills and soft skills, including the ability to communicate, coordinate, work under pressure, and solve problems [1]. Likewise, Trolian mentions that the frequency of student-teacher interaction is positively related to students' attitudes towards professional success [149].

The seventh research area corresponds to cluster 7 (orange); it is composed of 10 nodes and acquires the name of 'Employability', as it is the term with the highest occurrence. Thus, it is manifested that the employability skills profile (ESP) includes personal management, academic, and teamwork, which could increase the probability of professional success [150]. Likewise, the link between graduates' perceptions of their employability and professional success is evaluated [21]. Perceived employability is considered the variable that can measure the link between individual protein professional attitude, organizational learning practices, and professional success [151].

The eighth research area corresponds to cluster 8 (brown), made up of 8 nodes, called 'Career Development'. With accelerated economic, social, and technological changes, social skills are considered an absolute necessity to achieve a successful career [152]. Academics determined that graduates' employability and professional development are the characteristics that limit professional success [153].

\subsubsection{Cited authors Co-Citation Network}

This bibliometric analysis facilitates the structuring of a research field, resulting in more active study areas and emerging trends [50,154,155]. The analysis emphasizes the most prominent authors in this line of professional success research, and they are related through citation records $[53,60]$. The proposed bibliometric network construction was carried out with VOSviewer, using a similarity measure called association strength to analyse the co-citation data [78]. The professional success information base has 55,015 cited authors, of which 814 presented at least 20 citations. After cleaning the data, 764 were obtained with at least 20 citations. Table 5 includes the 15 authors with the highest number 
of citations, and Figure 6 shows the author's co-citations map, which contains 6 clusters, 764 nodes, 174,073 links, and a total link strength of 1,556,004.

Table 5. Top 15 most cited authors.

\begin{tabular}{cccccc}
\hline \multirow{2}{*}{ Ranking } & Author & Citations & $\begin{array}{c}\text { Total } \\
\text { Link Strength }\end{array}$ & Country & Affiliation \\
\hline 1 & Judge, T.A. & 1044 & 72,460 & United States & Fisher College of Business \\
2 & Hall, D.T. & 825 & 52,462 & United States & Questrom School of Business \\
3 & Arthur, M.B. & 688 & 42,638 & United States & Suffolk University \\
4 & Eby, L.T. & 608 & 41226 & United States & The University of Georgia \\
5 & Kraimer, M.L. & 575 & 42,599 & United States & Rutgers University-New Brunswick \\
6 & Feldman, D.C. & 550 & 36,412 & United States & Terry College of Business \\
7 & Greenhaus J.H. & 481 & 28,938 & United States & LeBow College of Business \\
8 & Seibert, S.E. & 473 & 33,726 & United States & Rutgers University-New Brunswick \\
9 & Ng, T.W.H. & 317 & 23,111 & Hong Kong & The University of Hong Kong \\
10 & Bretz, R.D. & 416 & 24,930 & United States & Mendoza College of Business \\
11 & Ferris, G.R. & 361 & 33,093 & United States & Florida State University \\
12 & Liden, R.C. & 361 & 28,532 & United States & University of Illinois at Chicago \\
13 & Baruch, Y. & 359 & 24,775 & United Kingdom & University of Southampton \\
14 & Boudreau, J.W. & 341 & 22,979 & United States & USC Marshall School of Business \\
15 & Cable, D.M. & 326 & 21,715 & United Kingdom & London Business School \\
\hline
\end{tabular}

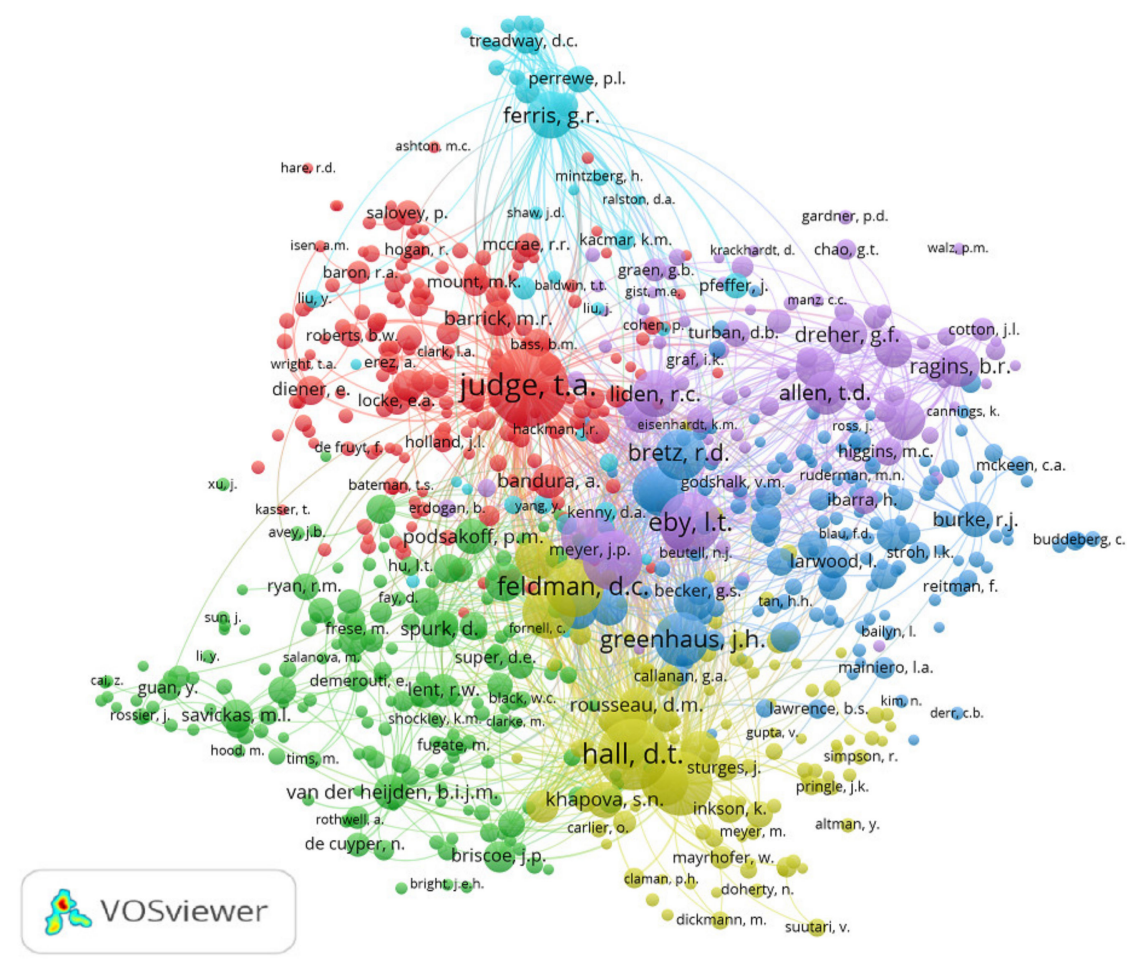

Figure 6. Co-citation cited authors network.

The intellectual structure of the field of professional success provided by the various approaches of the authors' co-citations was analysed through network analysis. Cluster 1 (red), 'Predictors of Career Success', comprises 195 authors, led by Judge, T.A. (1044), who is one of the most prominent authors and is linked to 762 authors; Barrick, M.R. (208), is related to 727 authors and Bandura, A. (193) which is related to 717 authors. In this cluster, according to Judge, he suggested that demographic, human capital, motivational, and organizational variables exhibit a notable change in objective professional success and professional satisfaction [83]. Subsequently, Judge also analysed the relationship between general mental ability (GMA) and extrinsic career success. As a result, people with high 
GMA had greater growth in extrinsic success because they achieved more education, job training and moved to more challenging jobs [156].

Cluster 2 (green), 'Proactive Personality and Career Success', comprises 175 authors, led by Crant, J.M. (249), which is related to 741 authors; Spurk, D. (226), who relates to 722 authors and Van Der Heijden, B.I.J.M. (202) who is related to 622 authors. Seibert's study stands out in this class, where a model was developed that relates proactive personality and professional success through four behavioural and cognitive mediators [87]. On the other hand, Abele suggested that professional success valued as objective professional achievements is indirectly positively related to life satisfaction, which is regularized by various subjective evaluations of success [128]. Finally, Van der Heijden admitted an employability model that optimizes career success in two age groups: for young people, employability ratings are related to objective career success outcomes. In people over 40 years of age, self-rated employability was positively related to promotions throughout professional life [157].

Cluster 3 (blue), 'Career Management', comprises 144 authors, led by Greenhaus, J.H. (481), which is related to 758 authors; Bretz, R.D. (416) linked to 760 authors and Boudreau, J.W. (341) also related to 760 authors. In this cluster, Chang empirically examined women workers' development networks and how their attributes intervene in their subjective professional success [158]. On the other hand, Bretz raised the theory of work adjustment (TWA) that relates to the person-environment adaptation and the satisfaction regarding the permanence in work [132]. Finally, Fuller extended previous career success models to include five-factor personality model traits and various extrinsic and intrinsic career success dimensions [89].

Cluster 4 (yellow), 'New Directions in Career Theory', comprises 116 authors, led by Hall, D.T. (825), which is related to 755 authors; Arthur, M.B. (668), which is related to 754 authors; Feldman, D.C. (550) related to 758 authors. Hall's research excels, examining the experiences of high-level professionals who, by reducing their workload, could achieve more favourable professional and family outcomes [159]. Finally, Beigi contributes to the work-family literature through the study of the work-family interface (WFI) around professional success [160].

Cluster 5 (purple), 'Mentoring in Career Success', comprises 94 authors, led by Eby, L.T. (608), which is related to 761 authors; Kraimer, M.L. (575), which is also related to 761 authors and Seibert, S.E. (473) related to 761 authors. In this cluster, Eby evaluated three career success criteria (perceived job satisfaction, perceived internal marketability, and perceived external marketability) considered as predictors of career success [131]. The short-term benefits of mentoring were explored (better job performance, recognition from others, rewarding experience, and loyal support base), announcing the long-term results of the mentor's career success, work attitudes, and behavioural intentions for the future mentor [161].

Cluster 6 (light blue), 'Work Effectiveness', comprises 40 authors, led by Ferris, G.R. (361), which is related to 665 authors; Perrewé, P.L. (118), which is related to 590 authors and Pfeffer, J. (104) related to 642 authors. In this class, an investigation by Jawahar stands out, which analysed data obtained from supervisors of professional employees to demonstrate the influence of task and contextual performance on work promotion judgments [162]. According to Perrewé, there is still evidence of unfair treatment in organizations based on the female gender, which is why the implications for stress and wellbeing at work were discussed, and ways of dealing with the deficiency of political skills in women were proposed [163].

\subsubsection{Scientific Cited Sources Co-Citation Network}

This type of analysis allows for the understanding of the field of study's structure by observing the related study areas according to the number of citations shared in the reference journals $[164,165]$. In the formation of this network, 345 sources were considered, 
which had at least 20 citations. The 15 main journals considered by their highest number of citations are observed in Table 6.

Table 6. Top 15 of the most cited sources.

\begin{tabular}{cccc}
\hline Ranking & Source & Citations & Total Link Strength \\
\hline 1 & Journal of Vocational Behavior & 3285 & 123,291 \\
2 & Journal of Applied Psychology & 2591 & 109,959 \\
3 & Academy of Management Journal & 1806 & 79,296 \\
4 & Journal of Organizational Behavior & 1726 & 71,863 \\
5 & Personnel Psychology & 1387 & 61,486 \\
6 & Journal of Management & 983 & 47,266 \\
7 & Career Development International & 838 & 34,509 \\
8 & Journal of Personality and Social Psychology & 822 & 37,840 \\
9 & Academy of Management Review & 710 & 33,172 \\
10 & International Journal of Human Resource & 564 & 26,115 \\
11 & Management & 547 & 25,063 \\
12 & Human Relations & 476 & 22,701 \\
13 & Journal of Occupational and Organizational & 405 & 18,544 \\
14 & Psychology & 403 & 19,052 \\
15 & Administrative Science Quarterly & 341 & 15,483 \\
\hline
\end{tabular}

In Figure 7, the cited sources co-citation network is shown, composed of five clusters (groups of journals) and 345 nodes (journals), which are distinguished by colour, showing 19,558 relationships between journals (links) and a total link strength out of 672,588.

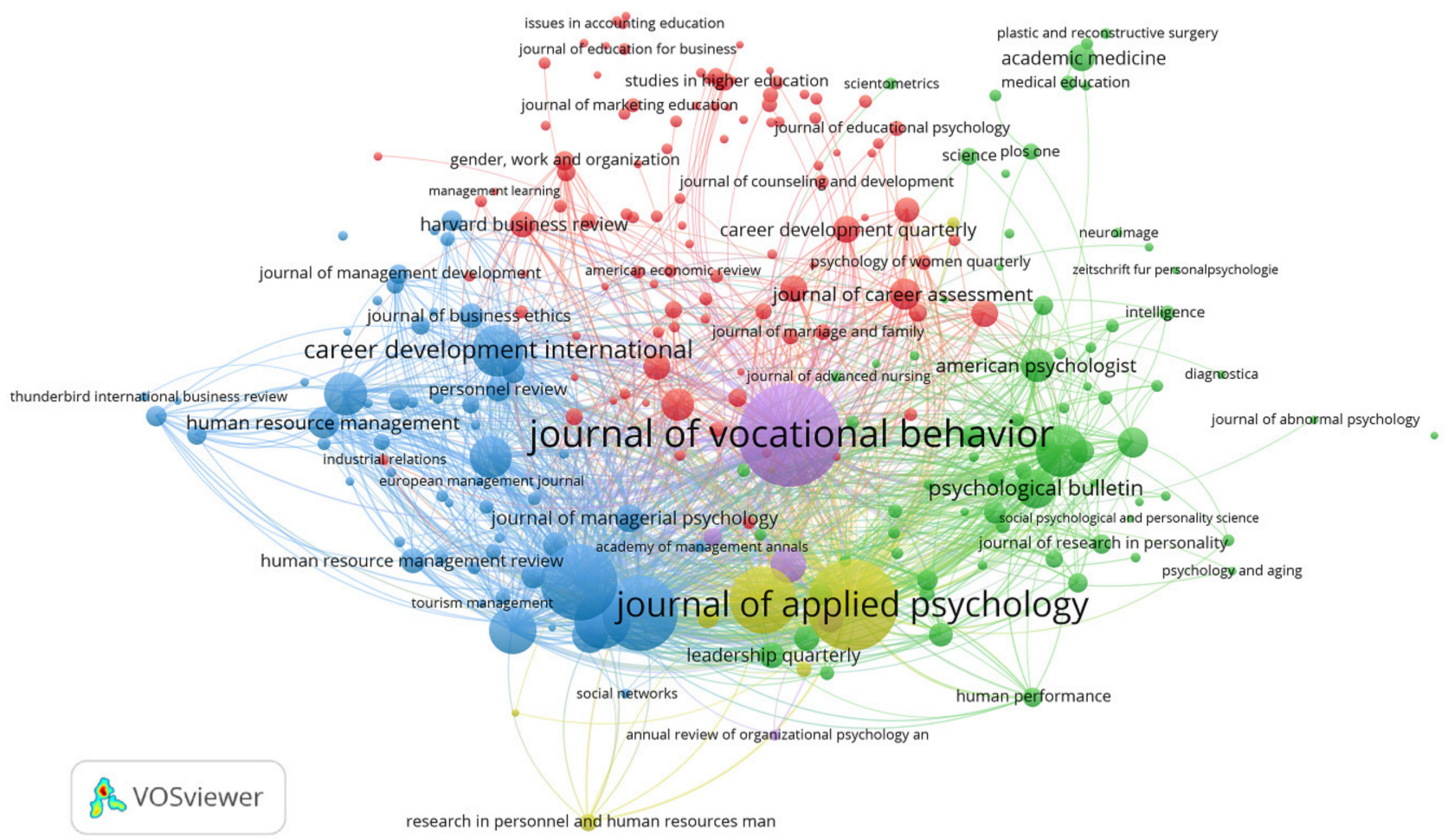

Figure 7. Co-citation cited sources network.

Cluster 1 (red) 'Sociology and Professional Development', with 100 journals, led by the American Sociological Review (322), a Q1 journal from the United States, with an H-Index of 185 , related to 223 journals and which is responsible for publishing topics of interest in sociology in general, research that advances the understanding of social processes, 
and methodological reforms. Second, the Journal of Career Assessment (303), a Q1 journal from the United States, with an H-Index of 56, related to 221 journals and publishes on vocational psychology, showing new research on behaviour career and the job. Finally, Career Development Quarterly (230), a Q2 journal from the United States, with an H-Index of 49 , is linked to 224 journals and contains publications about counselling, professional development, work, and professional education.

Cluster 2 (green) 'Interpersonal Relations and Scientific Psychology', includes 73 journals, led by the Journal of Personality and Social Psychology (822), a Q1 journal from the United States, with an H-Index of 351, related to 236 journals, and it publishes in three sections: (i) attitudes and social cognition, (ii) interpersonal relationships, and (iii) personality processes and individual differences. Second, Psychological Bulletin (476), a Q1 journal from the United States, with an H-Index of 296, related to 232 journals and publishes evaluative and integrative reviews on scientific psychology topics, considering both qualitative (narrative) and quantitative reviews. (meta-analysis). Third, American Psychologist (341), a Q1 journal from the United States, with an H-Index of 219, linked to 233 journals and publishes high-impact articles, including empirical reports, meta-analyses, and academic reviews on science, education, and science.

Cluster 3 (blue) 'Theory of Management and Organizational Behavior', includes 57 journals, led by the Academy of Management Journal (1806), a Q1 journal from the United States, with an H-Index of 304, related to 236 journals and publishes practical investigations that demonstrate, expand, or build the theory of management and favour its practice. Second, the Journal of Organizational Behavior (1726), a Q1 journal from the United States, with an H-Index of 164, related to 239 journals and is responsible for publishing research on organizational behaviour and all associated topics through levels of individual, group, and organizational study. Third, the Journal of Management (983), a Q1 journal from the United States, with an H-Index of 208, also linked to 239 journals and publishes articles on phenomena at the micro-, meso- and macro-scale of the workplace.

Cluster 4 (yellow) 'Psychology in the Labor Field', made up of eight journals, led by the Journal of Applied Psychology (2591), a Q1 journal from the United States, with an H-Index of 269 , related to 241 journals, in charge of publishing on empirical and theoretical studies that help to understand cognitive, motivational, affective, and behavioural psychological phenomena in work and organizational environments. Secondly, a Q1 journal from the United States, Personnel Psychology (1387), with an H-Index of 133, linked to 239 journals and includes publications on psychology focused on people in the workplace, covering topics related to human resource management and organizational behaviour mainly.

Cluster 5 (violet) 'Career Choice and Work Psychology' contains five journals, led by the Journal of Vocational Behavior (3285), a Q1 journal from the United States, with an HIndex of 141, related to 238 journals and publishes articles that contribute ground-breaking insights into the fields of career choice, career development, and job adjustment. Finally, the Journal of Occupational and Organizational Psychology (405), a Q1 journal from the United States, with an H-Index of 106, linked to 235 journals and publishes mainly on industrial, organizational, occupational, vocational, and personal psychology, behavioural aspects, and cognitive factors of labour relations and human factors.

\section{Discussion}

For more than 150 years, issues related to professional success have been partially studied. However, for this analysis, we have considered articles from 1990 in which a formal definition of this topic is already included [4] and its progressive evolution until 2020. To know future trends in professional success, it was observed that the most relevant studies in the period 1991-2000 had addressed the five major personality traits [64], the predictors of professional success [84], and the influence of political behaviour on the professional success [7], among others. Later, the second period (2001-2010) focused on the theory of professional success [64], employability [90,91], personality effects to achieve professional success [90], objective and subjective professional success [97,125,166-168], 
gender, and mentoring in career success [169-172]. Finally, in the period (2011-2020), gender [23,173], benefits of mentoring [114,174], and factors that determine professional success $[175,176]$ were mainly studied.

Seventy-six countries contribute to this field of study, with the United States, the United Kingdom, and Canada standing out, with more than 60 publications. The United States has three authors from the top 15 of the most cited authors, who come from Fisher College of Business (Judge T.A.) and Rutgers University-New Brunswick (Kraimer M.L. and Seibert S.E). Regarding the most representative journals, two areas predominate management development and psychology. The intellectual structure of professional success has been analysed under three parameters of the science mapping section. In the first place, the analysis of co-occurrence according to author keywords, represented in (Figure 5), where it is observed that the most relevant term is 'Career Success', with 276 co-occurrences in the database. In addition, it is related to 71 of the 92 terms analysed. It is worth mentioning that this term has a strong link with 'Career' (Cluster 1), 'Gender' (Cluster 2), and 'Career Development' (Cluster 8) mainly.

Second, the co-citation cited authors (see Figure 6) analysis shows the emerging lines of research about professional success. Cluster 1 (red), 'Predictors of Career Success', Cluster 2 (green), 'Proactive Personality and Career Success', Cluster 3 (blue), 'Career Management', Cluster 4 (yellow), 'New Directions in Career Theory', Cluster 5 (purple), 'Mentoring in Career Success', and Cluster 6 (light blue), 'Work Effectiveness'.

Third, the bibliometric map of co-citation by sources (see Figure 7) reflects the three outstanding journals: (i) Journal of Vocational Behavior, (ii) Journal of Applied Psychology, and (iii) Academy of Management Journal. These journals are from the United States. It is worth mentioning that the most cited article of the 1369 articles in the database was published in the Academy of Management Journal and reached 1221 citations. However, some documents within the 15 most cited publications have been published in Personnel Psychology and Perspectives on Psychological Science.

\section{Conclusions}

This study provides a bibliometric study of scientific articles related to professional success, which have been indexed in the Scopus database from 1991 to 2020. The analysis of scientific production shows the exponential growth in publications on this subject (see Figure 2), which was addressed in three periods: (i) 1991-2000, (ii) 2001-2010, and (iii) 2011-2020, where 147, 315, and 907 articles have been published, respectively. The first record from 1991 is titled "Career Paths and Career Success in the Early Career Stages of Male and Female MBAs" by authors Cox T.H. and Harquail C.V. in the Journal of Vocational Behaviour. Interest in this topic is evident in the last three years since it went from 106 articles in 2018 to 126 articles in 2019 and 2020. Delimiting the largest scientific production in North America, Europe, and Oceania (see Figure 4), which agrees with the analysis of bibliographic coupling by countries (Figure 3), the following countries stand out: the United States, the United Kingdom, and Canada, with 601, 133, and 93 articles, respectively.

The spatial distribution of publications on professional success is directly related to the most cited documents. In the first place, there is the publication of the author Seibert S.E. [5], which reached 1221 citations and was published jointly with Kraimer M.L., Liden R.C. The second most cited publication was that of Judge T.A. [64] and reached 1062 citations. Finally, the third most cited document was also the author Judge T.A. [83], which reached 766 citations. This type of analysis allows for the understanding of the field of study's structure by observing the related study areas according to the number of citations shared in the reference journals. This article facilitates the understanding of professional success's intellectual structure, considering the scientific production, geographical distribution, and contribution of the most cited journals, authors, and documents. In this sense, 1369 articles, 76 countries, 691 journals, and 3106 authors have been evaluated.

Considering the results that intervene in the analysis by science mapping. In the first instance, the analysis of the co-occurrence network by author keywords, which is 
represented by eight clusters (research areas) and 92 nodes (topics), where the most relevant topic was 'Career Success', which coincides with the name of the research area (Cluster 3). The remaining research areas are related to: 'Career and Gender'; 'Objective and Subjective Career Success'; 'Emotional Intelligence'; 'Job Satisfaction'; 'Higher Education'; 'Employability'; and 'Career Development'.

Second, the network of co-citations, according to authors, is made up of six groups that represent the various issues related to professional success: 'Predictors of Career Success' (Cluster 1); 'Proactive Personality and Career Success' (Cluster 2); 'Career Management' (Cluster 3); 'New Directions in Career Theory' (Cluster 4); 'Mentoring in Career Success' (Cluster 5); and 'Work Effectiveness' (Cluster 6). The most representative author is Judge T.A., located in Cluster 1 and is related to 754 of the 762 items analysed.

Third, the network of co-citations by scientific journals includes five clusters, which show the fields of knowledge that have been developed in the career success area: 'Sociohydrology and Professional Development' (Cluster 1); 'Interdisciplinary Relations and Social Psychology' (Cluster 2); 'Theory of Management and Organizational Behaviour' (Cluster 3); 'Psychology in the Labor Field' (Cluster 4); and 'Career Choice and Work Psychology' (Cluster 5). The most prominent journal in this area is the Journal of Vocational Behavior, which contains highly representative articles [5,88,130,177].

Regarding the methodological approach of this work, the following limitations are presented: (i) using a single database (Scopus), which, despite being a recognized and commonly used database in academia, may exclude some significant contributions in other databases (Web of Sciences and Dimensions, among others); in addition, (ii) that only articles were reviewed; and (iii) documents in English, which despite being one of the most used languages and important contributions on professional success, can be excluded. The bibliometric approach is reliable and has been used by researchers worldwide in several studies, including [178-180]. The study required the use of some descriptors related to career success to obtain adequate information regarding the subject studied. These descriptors were subjected to a triangular search (title-abstract-keywords), where the title of the document helps to recognize the central focus of the study and the importance that the authors give to the topic; this is complemented by the use of the abstract and keywords to broadening this approach, based on research related to the term.

Supplementary Materials: The following are available online at https:/ /www.mdpi.com/article/10 $.3390 /$ su13094625/s1, Table S1: Results of the co-occurrence network of author keywords.

Author Contributions: Conceptualization, P.C.-M., N.M.-B., and R.P.-S.; methodology, P.C.-M., N.M.B., and R.P.-S.; writing — original draft preparation, P.C.-M., N.M.-B., and R.P.-S.; writing—review and editing, P.C.-M., N.M.-B., R.P.-S., J.G., and A.R.; supervision, P.C.-M. All authors have read and agreed to the published version of the manuscript.

Funding: This research received no external funding.

Institutional Review Board Statement: Not applicable.

Informed Consent Statement: Not applicable.

Data Availability Statement: Not applicable.

Acknowledgments: Thanks to CIPAT-ESPOL for the support and accompaniment in the development of this publication and specially to Eng. Lady Bravo-Montero for her collaboration and helpful spirit. The preparation of this study counted with the collaboration of various scientific research projects, such as the academic projects of the ESPOL University (Escuela Superior Politécnica del Litoral) with code no. CIPAT-01-2018 Registro del Patrimonio Geológico y Minero y su incidencia en la defensa y preservación de la geodiversidad en Ecuador" (Registry of Geological and Mining Heritage and its impact on the defense and preservation of geodiversity in Ecuador); and the support of NOVA Science Research Associates and the project of UTEQ "Prediction and assessment of the professional success of university graduates", with code 44 .

Conflicts of Interest: The authors declare no conflict of interest. 


\section{References}

1. Ummatqul Qizi, K.N. Soft skills development in higher education. Univers. J. Educ. Res. 2020, 8, 1916-1925. [CrossRef]

2. Pacáková, Z.; Jindrová, A. Information Benefit of Graduates Follow-up Surveys. J. Effic. Responsib. Educ. Sci. $2011,4,129-141$.

3. Oplatka, I.; Mimon, R. Women principals' conceptions of job satisfaction and dissatisfaction: An alternative view? Int. J. Leadersh. Educ. 2008, 11, 135-153. [CrossRef]

4. Aryee, S.; Chay, Y.W.; Tan, H.H. An Examination of the Antecedents of Subjective Career Success Among a Managerial Sample in Singapore. Hum. Relat. 1994, 47, 487-509. [CrossRef]

5. Seibert, S.E.; Kraimer, M.L. The Five-Factor Model of Personality and Career Success. J. Vocat. Behav. 2001, 58, 1-21. [CrossRef]

6. NG, T.W.H.; Eby, L.T.; Sorensen, K.L.; Feldman, D.C. Predictors of Objective and Subjective Career Success: A Meta-Analysis. Pers. Psychol. 2005, 58, 367-408. [CrossRef]

7. Judge, T.A.; Bretz, R.D. Political Influence Behavior and Career Success. J. Manag. 1994, 20, 43-65. [CrossRef]

8. Seibert, S.E.; Crant, J.M.; Kraimer, M.L. Proactive personality and career success. J. Appl. Psychol. 1999, 84, 416-427. [CrossRef]

9. Gattiker, U.E.; Larwood, L. Subjective career success: A study of managers and support personnel. J. Bus. Psychol. 1986, 1, 78-94. [CrossRef]

10. Kirchmeyer, C. Determinants of Managerial Career Success: Evidence and Explanation of Male/Female Differences. J. Manag. 1998, 24, 673-692. [CrossRef]

11. Peluchette, J.V.E. Subjective Career Success: The Influence of Individual Difference, Family, and Organizational Variables. J. Vocat. Behav. 1993, 43, 198-208. [CrossRef]

12. NG, T.W.H.; Feldman, D.C. Subjective career success: A meta-analytic review. J. Vocat. Behav. 2014, 85, 169-179. [CrossRef]

13. Cope, P.M. The Women of "Who's Who": A Statistical Study. Soc. Forces 1928, 7, 212-223. [CrossRef]

14. Heslin, P.A. Conceptualizing and evaluating career success. J. Organ. Behav. 2005, 26, 113-136. [CrossRef]

15. Raluy Alonso, Á. El concepto estadounidense de "éxito" frente a su homónimo español: Dos visiones sociológica, semántica y etimológicamente diferentes. ELUA. Estud. Lingüíst. Univ. Alicant. 2012, 269-288. [CrossRef]

16. Canal Domínguez, J.F.; Rodríguez Gutiérrez, C. Universidad pública frente a universidad privada: ¿qué efectos tiene sobre el éxito profesional de los universitarios españoles? / A Public University or a Private University: What Effect does this Choice have on the Professional Success of Graduates in S. Rev. Esp. Investig. Sociol. 2020, 169. [CrossRef]

17. Delgado, A.; Saletti-Cuesta, L.; López-Fernández, L.A.; Toro-Cárdenas, S.; Luna del Castillo, J.d.D. Professional Success and Gender in Family Medicine. Eval. Health Prof. 2016, 39, 87-99. [CrossRef]

18. Tlaiss, H.; Kauser, S. The importance of wasta in the career success of Middle Eastern managers. J. Eur. Ind. Train. 2011, 35, 467-486. [CrossRef]

19. Spangler, W.D. Validity of questionnaire and TAT measures of need for achievement: Two meta-analyses. Psychol. Bull. 1992, 112, 140-154. [CrossRef]

20. Kim, M.; Beehr, T.A. Can Empowering Leaders Affect Subordinates' Well-Being and Careers Because They Encourage Subordinates' Job Crafting Behaviors? J. Leadersh. Organ. Stud. 2018, 25, 184-196. [CrossRef]

21. Niu, Y.; Hunter-Johnson, Y.; Xu, X.; Liu, T. Self-Perceived Employability and Subjective Career Success: Graduates of a Workforce Education and Development Program. J. Contin. High. Educ. 2019, 67, 55-71. [CrossRef]

22. Walsh, L.C.; Boehm, J.K.; Lyubomirsky, S. Does Happiness Promote Career Success? Revisiting the Evidence. J. Career Assess. 2018, 26, 199-219. [CrossRef]

23. Crompton, R.; Lyonette, C. Women's Career Success and Work-life Adaptations in the Accountancy and Medical Professions in Britain. Gender Work Organ. 2011, 18, 231-254. [CrossRef]

24. Goh, S.C. Sex differences in perceptions of interpersonal work style, career emphasis, supervisory mentoring behavior, and job satisfaction. Sex Roles 1991, 24, 701-710. [CrossRef]

25. De Haro, J. El Papel de la Inteligencia General, la Personalidad y la Inteligencia Emocional en el Éxito Profesional al Inicio de la Carrera; Universidad de Alicante: San Vicente del Raspeig, Spain, 2014.

26. Koh, H.C.; Boo, E.H.Y. The link between organizational ethics and job satisfaction: A study of managers in Singapore. J. Bus. Ethics 2001, 29, 309-324. [CrossRef]

27. Judiesch, M.K.; Lyness, K.S. Left Behind? The Impact of Leaves of Absence on Managers' Career Success. Acad. Manag. J. 1999, 42, 641-651. [CrossRef]

28. Forest, J.; Mageau, G.A.; Sarrazin, C.; Morin, E.M. “Work is my passion”: The different affective, behavioural, and cognitive consequences of harmonious and obsessive passion toward work. Can. J. Adm. Sci. Rev. Can. Sci. Adm. 2011, 28, 27-40. [CrossRef]

29. Robinson, D.A.G.; Reilly, B.A. Women Engineers: A Study of Educational Preparation and Professional Success. J. Eng. Educ. 1993, 82, 78-82. [CrossRef]

30. Pinelli, T.E.; Barclay, R.O.; Kennedy, J.M. Workplace communications skills and the value of communications and information use skills instruction-engineering students' perspectives. In Proceedings of the 1995 IEEE International Professional Communication Conference. IPCC 95 Proceedings. Smooth Sailing to the Future; IEEE: Savannah, GA, USA, 1995; pp. 161-165.

31. Burke, R.J.; Kurucz, E. Demographic Characteristics of Canadian Women Corporate Directors. Psychol. Rep. 1998, 83, 461-462. [CrossRef]

32. Morreale, S.P.; Pearson, J.C. Why Communication Education is Important: The Centrality of the Discipline in the 21st Century. Commun. Educ. 2008, 57, 224-240. [CrossRef] 
33. Costa, P.T.J.; McCrae, R.R. NEO PI-R. Revised Neo Personality Inventory and NEO Five-Factor Inventory (NEO-FFI); Psychological Assessment Resources: Odessa, FL, USA, 2008.

34. Khan, M.B.; Kukalis, S. MIS professionals: Education and performance. Inf. Manag. 1990, 19, 249-255. [CrossRef]

35. Wiggins, C.; Bowman, S.Y. Career Success and Life Satisfaction for Female and Male Healthcare Managers. Hosp. Top. 2000, 78, 5-10. [CrossRef] [PubMed]

36. Buckley, L.M.; Sanders, K.; Shih, M.; Hampton, C.L. Attitudes of Clinical Faculty About Career Progress, Career Success and Recognition, and Commitment to Academic Medicine. Arch. Intern. Med. 2000, 160, 2625. [CrossRef]

37. Knouse, S.B. Virtual mentors: Mentoring on the internet. J. Employ. Couns. 2001, 38, 162-169. [CrossRef]

38. Afarian, R.; Kleiner, B.H. The relationship between grades and career success. Manag. Res. News 2003, 26, 42-51. [CrossRef]

39. McDonald, K.S.; Hite, L.M. The Next Generation of Career Success: Implications for HRD. Adv. Dev. Hum. Resour. 2008, 10, 86-103. [CrossRef]

40. Gault, J.; Redington, J.; Schlager, T. Undergraduate Business Internships and Career Success: Are They Related? J. Mark. Educ. 2000, 22, 45-53. [CrossRef]

41. Cobo, M.J.; Martínez, M.A.; Gutiérrez-Salcedo, M.; Fujita, H.; Herrera-Viedma, E. 25years at Knowledge-Based Systems: A bibliometric analysis. Knowl. Based Syst. 2015, 80, 3-13. [CrossRef]

42. Li, T.; Ho, Y.-S.; Li, C.-Y. Bibliometric analysis on global Parkinson's disease research trends during 1991. Neurosci. Lett. 2008, 441, 248-252. [CrossRef] [PubMed]

43. Van Eck, N.J.; Waltman, L. Citation-based clustering of publications using CitNetExplorer and VOSviewer. Scientometrics 2017, 111, 1053-1070. [CrossRef]

44. Tranfield, D.; Denyer, D.; Smart, P. Towards a Methodology for Developing Evidence-Informed Management Knowledge by Means of Systematic Review. Br. J. Manag. 2003, 14, 207-222. [CrossRef]

45. Fahimnia, B.; Sarkis, J.; Davarzani, H. Green supply chain management: A review and bibliometric analysis. Int. J. Prod. Econ. 2015, 162, 101-114. [CrossRef]

46. Herrera-Franco, G.; Montalván-Burbano, N.; Carrión-Mero, P.; Apolo-Masache, B.; Jaya-Montalvo, M. Research Trends in Geotourism: A Bibliometric Analysis Using the Scopus Database. Geosciences 2020, 10, 379. [CrossRef]

47. Keathley-Herring, H.; Van Aken, E.; Gonzalez-Aleu, F.; Deschamps, F.; Letens, G.; Orlandini, P.C. Assessing the maturity of a research area: Bibliometric review and proposed framework. Scientometrics 2016, 109, 927-951. [CrossRef]

48. Do Prado, J.W.; de Castro Alcântara, V.; de Melo Carvalho, F.; Vieira, K.C.; Machado, L.K.C.; Tonelli, D.F. Multivariate analysis of credit risk and bankruptcy research data: A bibliometric study involving different knowledge fields (1968-2014). Scientometrics 2016, 106, 1007-1029. [CrossRef]

49. Merigó, J.M.; Blanco-Mesa, F.; Gil-Lafuente, A.M.; Yager, R.R. Thirty Years of the International Journal of Intelligent Systems: A Bibliometric Review. Int. J. Intell. Syst. 2017, 32, 526-554. [CrossRef]

50. Montalván-Burbano, N.; Pérez-Valls, M.; Plaza-Úbeda, J.; Foroudi, P. Analysis of scientific production on organizational innovation. Cogent Bus. Manag. 2020, 7, 1745043. [CrossRef]

51. Ma, R.; Ho, Y.-S. Comparison of environmental laws publications in Science Citation Index Expanded and Social Science Index: A bibliometric analysis. Scientometrics 2016, 109, 227-239. [CrossRef]

52. Cobo, M.J.; López-Herrera, A.G.; Herrera-Viedma, E.; Herrera, F. An approach for detecting, quantifying, and visualizing the evolution of a research field: A practical application to the Fuzzy Sets Theory field. J. Informetr. 2011, 5, 146-166. [CrossRef]

53. Zupic, I.; Čater, T. Bibliometric Methods in Management and Organization. Organ. Res. Methods 2015, 18, 429-472. [CrossRef]

54. Maldonado-Erazo, C.P.; Álvarez-García, J.; del Río-Rama, M.d.l.C.; Correa-Quezada, R. Corporate Social Responsibility and Performance in SMEs: Scientific Coverage. Sustainability 2020, 12, 2332. [CrossRef]

55. Chandra, Y. Mapping the evolution of entrepreneurship as a field of research (1990-2013): A scientometric analysis. PLoS ONE 2018, 13, e0190228. [CrossRef]

56. Abad-Segura, E.; de la Fuente, A.B.; González-Zamar, M.-D.; Belmonte-Ureña, L.J. Effects of Circular Economy Policies on the Environment and Sustainable Growth: Worldwide Research. Sustainability 2020, 12, 5792. [CrossRef]

57. Durán-Sánchez, A.; de la Del Río-Rama, M.C.; Álvarez-García, J.; García-Vélez, D.F. Mapping of scientific coverage on education for Entrepreneurship in Higher Education. J. Enterp. Communities People Places Glob. Econ. 2019, 13, 84-104. [CrossRef]

58. Hallinger, P.; Nguyen, V.-T. Mapping the Landscape and Structure of Research on Education for Sustainable Development: A Bibliometric Review. Sustainability 2020, 12, 1947. [CrossRef]

59. Herrera-Franco, G.; Montalván-Burbano, N.; Carrión-Mero, P.; Jaya-Montalvo, M.; Gurumendi-Noriega, M. Worldwide Research on Geoparks through Bibliometric Analysis. Sustainability 2021, 13, 1175. [CrossRef]

60. Briones-Bitar, J.; Carrión-Mero, P.; Montalván-Burbano, N.; Morante-Carballo, F. Rockfall Research: A Bibliometric Analysis and Future Trends. Geosciences 2020, 10, 403. [CrossRef]

61. Tadmor, C.T.; Galinsky, A.D.; Maddux, W.W. Getting the most out of living abroad: Biculturalism and integrative complexity as key drivers of creative and professional success. J. Pers. Soc. Psychol. 2012, 103, 520-542. [CrossRef]

62. Romanelli, F.; Cain, J.; Smith, K.M. Emotional Intelligence as a Predictor of Academic and/or Professional Success. Am. J. Pharm. Educ. 2006, 70, 69. [CrossRef] [PubMed]

63. Seibert, S.E.; Kraimer, M.L.; Liden, R.C. A Social Capital Therory of Career Success. Acad. Manag. J. 2001, 44, 219-237. [CrossRef] 
64. Judge, T.A.; Higgins, C.A.; Thoresen, C.J.; Barrick, M.R. The Big Five Personality Traits, General Mental Ability, and Career Success across the Life Span. Pers. Psychol. 1999, 52, 621-652. [CrossRef]

65. Mongeon, P.; Paul-Hus, A. The journal coverage of Web of Science and Scopus: A comparative analysis. Scientometrics 2016, 106, 213-228. [CrossRef]

66. Del Río-Rama, M.; Maldonado-Erazo, C.; Álvarez-García, J.; Durán-Sánchez, A. Cultural and Natural Resources in Tourism Island: Bibliometric Mapping. Sustainability 2020, 12, 724. [CrossRef]

67. Meseguer-Sánchez, V.; Abad-Segura, E.; Belmonte-Ureña, L.J.; Molina-Moreno, V. Examining the Research Evolution on the Socio-Economic and Environmental Dimensions on University Social Responsibility. Int. J. Environ. Res. Public Health 2020, 17, 4729. [CrossRef]

68. Álvarez-García, J.; Durán-Sánchez, A.; del Río-Rama, M.C. Systematic bibliometric analysis on Kaizen in scientific journals. TQM J. 2018, 30, 356-370. [CrossRef]

69. Maldonado-Erazo, C.P.; Álvarez-García, J.; del Río-Rama, M.C.; de la Durán-Sánchez, A. Scientific Mapping on the Impact of Climate Change on Cultural and Natural Heritage: A Systematic Scientometric Analysis. Land 2021, 10, 76. [CrossRef]

70. Najmi, A.; Rashidi, T.H.; Abbasi, A.; Travis Waller, S. Reviewing the transport domain: An evolutionary bibliometrics and network analysis. Scientometrics 2017, 110, 843-865. [CrossRef]

71. Caputo, A.; Marzi, G.; Pellegrini, M.M.; Rialti, R. Conflict management in family businesses. Int. J. Confl. Manag. 2018, 29 , 519-542. [CrossRef]

72. Salmerón-Manzano, E.; Manzano-Agugliaro, F. Worldwide Research on Low Cost Technologies through Bibliometric Analysis. Inventions 2020, 5, 9. [CrossRef]

73. Van Eck, N.J.; Waltman, L. Software survey: VOSviewer, a computer program for bibliometric mapping. Scientometrics 2010, 84, 523-538. [CrossRef] [PubMed]

74. Payán-Sánchez, B.; Belmonte-Ureña, L.J.; Plaza-Úbeda, J.A.; Vazquez-Brust, D.; Yakovleva, N.; Pérez-Valls, M. Open Innovation for Sustainability or Not: Literature Reviews of Global Research Trends. Sustainability 2021, 13, 1136. [CrossRef]

75. Velasco-Muñoz, J.; Aznar-Sánchez, J.; Belmonte-Ureña, L.; Román-Sánchez, I. Sustainable Water Use in Agriculture: A Review of Worldwide Research. Sustainability 2018, 10, 1084. [CrossRef]

76. Chernysh, Y.; Roubík, H. International Collaboration in the Field of Environmental Protection: Trend Analysis and COVID-19 Implications. Sustainability 2020, 12, 384. [CrossRef]

77. León-Castro, M.; Rodríguez-Insuasti, H.; Montalván-Burbano, N.; Victor, J.A. Bibliometrics and Science Mapping of Digital Marketing. In Proceedings of the Marketing and Smart Technologies; Rocha, Á., Reis, J.L., Peter, M.K., Cayolla, R., Loureiro, S., Bogdanović, Z., Eds.; Springer Singapore: Singapore, 2021; pp. 95-107.

78. Md Khudzari, J.; Kurian, J.; Tartakovsky, B.; Raghavan, G.S.V. Bibliometric analysis of global research trends on microbial fuel cells using Scopus database. Biochem. Eng. J. 2018, 136, 51-60. [CrossRef]

79. Hinojo-Lucena, F.-J.; Aznar-Díaz, I.; Cáceres-Reche, M.-P.; Romero-Rodríguez, J.-M. Artificial Intelligence in Higher Education: A Bibliometric Study on its Impact in the Scientific Literature. Educ. Sci. 2019, 9, 51. [CrossRef]

80. Cox, T.H.; Harquail, C. V Career paths and career success in the early career stages of male and female MBAs. J. Vocat. Behav. 1991, 39, 54-75. [CrossRef]

81. Dreher, G.F.; Bretz, R.D. Cognitive ability and career attainment: Moderating effects of early career success. J. Appl. Psychol. 1991, 76, 392-397. [CrossRef]

82. Russo, N.F.; Kelly, R.M.; Deacon, M. Gender and success-related attributions: Beyond individualistic conceptions of achievement. Sex Roles 1991, 25, 331-350. [CrossRef]

83. Judge, T.A.; Cable, D.M.; Boudreau, J.W.; Bretz, R.D. An Empirical Investigation of the Predictors of Executive Career Success. Pers. Psychol. 1995, 48, 485-519. [CrossRef]

84. Baroudi, J.J.; Igbaria, M. An Examination of Gender Effects on Career Success of Information Systems Employees. J. Manag. Inf. Syst. 1994, 11, 181-201. [CrossRef]

85. Wayne, S.J.; Liden, R.C.; Kraimer, M.L.; Graf, I.K. The role of human capital, motivation and supervisor sponsorship in predicting career success. J. Organ. Behav. 1999, 20, 577-595. [CrossRef]

86. Collins, P.M. Does Mentorship among Social Workers Make a Difference? An Empirical Investigation of Career Outcomes. Soc. Work 1994. [CrossRef]

87. Seibert, S.E.; Kraimer, M.L.; Crant, J.M. What do Proactive People do? A Longitudinal Model Linking Proactive Personality and Career Success. Pers. Psychol. 2001, 54, 845-874. [CrossRef]

88. Fuller, B.; Marler, L.E. Change driven by nature: A meta-analytic review of the proactive personality literature. J. Vocat. Behav. 2009, 75, 329-345. [CrossRef]

89. Boudreau, J.W.; Boswell, W.R.; Judge, T.A. Effects of Personality on Executive Career Success in the United States and Europe. J. Vocat. Behav. 2001, 58, 53-81. [CrossRef]

90. Van Der Heijde, C.M.; Van Der Heijden, B.I.J.M. A competence-based and multidimensional operationalization and measurement of employability. Hum. Resour. Manag. 2006, 45, 449-476. [CrossRef]

91. Rothwell, A.; Arnold, J. Self-perceived employability: Development and validation of a scale. Pers. Rev. 2007, 36, 23-41. [CrossRef]

92. Forret, M.L.; Dougherty, T.W. Networking behaviors and career outcomes: Differences for men and women? J. Organ. Behav. 2004, 25, 419-437. [CrossRef] 
93. Wolff, H.-G.; Moser, K. Effects of networking on career success: A longitudinal study. J. Appl. Psychol. 2009, 94, 196-206. [CrossRef]

94. Underhill, C.M. The effectiveness of mentoring programs in corporate settings: A meta-analytical review of the literature. J. Vocat. Behav. 2006, 68, 292-307. [CrossRef]

95. Ensher, E.A.; Thomas, C.; Murphy, S.E. Comparison of traditional, step-ahead, and peer mentoring on protégés' support, satisfaction, and perceptions of career success: A social exchange perspective. J. Bus. Psychol. 2001, 15, 419-438. [CrossRef]

96. Day, R.; Allen, T.D. The relationship between career motivation and self-efficacy with protégé career success. J. Vocat. Behav. 2004, 64, 72-91. [CrossRef]

97. Abele, A.E.; Spurk, D. The longitudinal impact of self-efficacy and career goals on objective and subjective career success. J. Vocat. Behav. 2009, 74, 53-62. [CrossRef]

98. De Vos, A.; Soens, N. Protean attitude and career success: The mediating role of self-management. J. Vocat. Behav. 2008, 73, 449-456. [CrossRef]

99. Erdogan, B.; Kraimer, M.L.; Liden, R.C. Work Value Congruence and Intrinsic Career Success: The Compensatory Roles of Leader-Member Exchange and Perceived Organizational Support. Pers. Psychol. 2004, 57, 305-332. [CrossRef]

100. Boehm, J.K.; Lyubomirsky, S. Does Happiness Promote Career Success? J. Career Assess. 2008, 16, 101-116. [CrossRef]

101. Judge, T.A.; Cable, D.M. The Effect of Physical Height on Workplace Success and Income: Preliminary Test of a Theoretical Model. J. Appl. Psychol. 2004, 89, 428-441. [CrossRef]

102. De Vos, A.; De Hauw, S.; Van der Heijden, B.I.J.M. Competency development and career success: The mediating role of employability. J. Vocat. Behav. 2011, 79, 438-447. [CrossRef]

103. Rudolph, C.W.; Lavigne, K.N.; Zacher, H. Career adaptability: A meta-analysis of relationships with measures of adaptivity, adapting responses, and adaptation results. J. Vocat. Behav. 2017, 98, 17-34. [CrossRef]

104. Zacher, H. Career adaptability predicts subjective career success above and beyond personality traits and core self-evaluations. J. Vocat. Behav. 2014, 84, 21-30. [CrossRef]

105. Koen, J.; Klehe, U.-C.; Van Vianen, A.E.M. Training career adaptability to facilitate a successful school-to-work transition. J. Vocat. Behav. 2012, 81, 395-408. [CrossRef]

106. Leslie, L.M.; Manchester, C.F.; Park, T.-Y.; Mehng, S.A. Flexible Work Practices: A Source of Career Premiums or Penalties? Acad. Manag. J. 2012, 55, 1407-1428. [CrossRef]

107. Xie, B.; Xia, M.; Xin, X.; Zhou, W. Linking calling to work engagement and subjective career success: The perspective of career construction theory. J. Vocat. Behav. 2016, 94, 70-78. [CrossRef]

108. Fang, R.; Landis, B.; Zhang, Z.; Anderson, M.H.; Shaw, J.D.; Kilduff, M. Integrating Personality and Social Networks: A MetaAnalysis of Personality, Network Position, and Work Outcomes in Organizations. Organ. Sci. 2015, 26, 1243-1260. [CrossRef]

109. Westerman, J.W.; Bergman, J.Z.; Bergman, S.M.; Daly, J.P. Are Universities Creating Millennial Narcissistic Employees? An Empirical Examination of Narcissism in Business Students and Its Implications. J. Manag. Educ. 2012, 36, 5-32. [CrossRef]

110. Baron, R.A.; Hmieleski, K.M.; Henry, R.A. Entrepreneurs' dispositional positive affect: The potential benefits-And potential costs—of being "up". J. Bus. Ventur. 2012, 27, 310-324. [CrossRef]

111. Spurk, D.; Kauffeld, S.; Barthauer, L.; Heinemann, N.S.R. Fostering networking behavior, career planning and optimism, and subjective career success: An intervention study. J. Vocat. Behav. 2015, 87, 134-144. [CrossRef]

112. Chudzikowski, K. Career transitions and career success in the 'new' career era. J. Vocat. Behav. 2012, 81, 298-306. [CrossRef]

113. Guan, Y.; Zhou, W.; Ye, L.; Jiang, P.; Zhou, Y. Perceived organizational career management and career adaptability as predictors of success and turnover intention among Chinese employees. J. Vocat. Behav. 2015, 88, 230-237. [CrossRef]

114. Stamm, M.; Buddeberg-Fischer, B. The impact of mentoring during postgraduate training on doctors' career success. Med. Educ. 2011, 45, 488-496. [CrossRef]

115. Dashper, K. Challenging the gendered rhetoric of success? The limitations of women-only mentoring for tackling gender inequality in the workplace. Gender Work Organ. 2019, 26, 541-557. [CrossRef]

116. Blokker, R.; Akkermans, J.; Tims, M.; Jansen, P.; Khapova, S. Building a sustainable start: The role of career competencies, career success, and career shocks in young professionals' employability. J. Vocat. Behav. 2019, 112, 172-184. [CrossRef]

117. Belsky, D.W.; Domingue, B.W.; Wedow, R.; Arseneault, L.; Boardman, J.D.; Caspi, A.; Conley, D.; Fletcher, J.M.; Freese, J.; Herd, P.; et al. Genetic analysis of social-class mobility in five longitudinal studies. Proc. Natl. Acad. Sci. USA 2018, 115, E7275-E7284. [CrossRef] [PubMed]

118. Chen, Q.; Beaty, R.E.; Wei, D.; Yang, J.; Sun, J.; Liu, W.; Yang, W.; Zhang, Q.; Qiu, J. Longitudinal Alterations of Frontoparietal and Frontotemporal Networks Predict Future Creative Cognitive Ability. Cereb. Cortex 2018, 28, 103-115. [CrossRef] [PubMed]

119. Suutari, V.; Brewster, C.; Mäkelä, L.; Dickmann, M.; Tornikoski, C. The Effect of International Work Experience on the Career Success of Expatriates: A Comparison of Assigned and Self-Initiated Expatriates. Hum. Resour. Manag. 2018, 57, 37-54. [CrossRef]

120. Smale, A.; Bagdadli, S.; Cotton, R.; Dello Russo, S.; Dickmann, M.; Dysvik, A.; Gianecchini, M.; Kaše, R.; Lazarova, M.; Reichel, A.; et al. Proactive career behaviors and subjective career success: The moderating role of national culture. J. Organ. Behav. 2019, 40, 105-122. [CrossRef]

121. Andreo-Martínez, P.; Ortiz-Martínez, V.M.; García-Martínez, N.; de los Ríos, A.P.; Hernández-Fernández, F.J.; Quesada-Medina, J. Production of biodiesel under supercritical conditions: State of the art and bibliometric analysis. Appl. Energy 2020, 264, 114753. [CrossRef] 
122. Carrión-Mero, P.; Montalván-Burbano, N.; Paz-Salas, N.; Morante-Carballo, F. Volcanic Geomorphology: A Review of Worldwide Research. Geosciences 2020, 10, 347. [CrossRef]

123. Solla-Price, D.; John, D. Little Science, Big Science; Columbia University Press: New York, NY, USA, 1963.

124. Kraimer, M.L.; Greco, L.; Seibert, S.E.; Sargent, L.D. An Investigation of Academic Career Success: The New Tempo of Academic Life. Acad. Manag. Learn. Educ. 2019, 18, 128-152. [CrossRef]

125. Abele, A.E.; Spurk, D. How do objective and subjective career success interrelate over time? J. Occup. Organ. Psychol. 2009, 82, 803-824. [CrossRef]

126. Abele, A.E.; Spurk, D.; Volmer, J. The construct of career success: Measurement issues and an empirical example. Zeitschrift Arbeitsmarktforsch 2011, 43, 195-206. [CrossRef]

127. Abele, A.E.; Spurk, D. The dual impact of gender and the influence of timing of parenthood on men's and women's career development: Longitudinal findings. Int. J. Behav. Dev. 2011, 35, 225-232. [CrossRef]

128. Abele, A.E.; Hagmaier, T.; Spurk, D. Does Career Success Make You Happy? The Mediating Role of Multiple Subjective Success Evaluations. J. Happiness Stud. 2016, 17, 1615-1633. [CrossRef]

129. Nosek, B.A.; Spies, J.R.; Motyl, M. Scientific Utopia: II. Restructuring Incentives and Practices to Promote Truth Over Publishability. Perspect. Psychol. Sci. 2012, 7, 615-631. [CrossRef]

130. Parasuraman, S.; Purohit, Y.S.; Godshalk, V.M.; Beutell, N.J. Work and Family Variables, Entrepreneurial Career Success, and Psychological Well-Being. J. Vocat. Behav. 1996, 48, 275-300. [CrossRef]

131. Eby, L.T.; Butts, M.; Lockwood, A. Predictors of success in the era of the boundaryless career. J. Organ. Behav. 2003, 24, 689-708. [CrossRef]

132. Bretz, R.D., Jr.; Judge, T.A. Person-Organization Fit and the Theory of Work Adjustment: Implications for Satisfaction, Tenure, and Career Success. J. Vocat. Behav. 1994, 44, 32-54. [CrossRef]

133. Waltman, L.; van Eck, N.J.; Noyons, E.C.M. A unified approach to mapping and clustering of bibliometric networks. J. Informetr. 2010, 4, 629-635. [CrossRef]

134. Sosik, J.J.; Godshalk, V.M.; Yammarino, F.J. Transformational leadership, learning goal orientation, and expectations for career success in mentor-protégé relationships: A multiple levels of analysis perspective. Leadersh. Q. 2004, 15, 241-261. [CrossRef]

135. Broadbridge, A.; Parsons, E. Gender and career choice. Career Dev. Int. 2005, 10, 80-97. [CrossRef]

136. Dubbelt, L.; Rispens, S.; Demerouti, E. Gender discrimination and job characteristics. Career Dev. Int. 2016, 21, 230-245. [CrossRef]

137. Jang, S.; Allen, T.D.; Regina, J. Office Housework, Burnout, and Promotion: Does Gender Matter? J. Bus. Psychol. 2020. [CrossRef]

138. Abiddin, N.Z. Developings an Informal Mentoring Relationship in Career Advancement and Psychosocial of Young Graduate Entrepreneurs for Human Resource Development. Res. J. Appl. Sci. 2013, 8, 321-329. [CrossRef]

139. Koekemoer, E.; Crafford, A. Exploring subjective career success using the Kaleidoscope Career Model. SA J. Ind. Psychol. 2019, 45. [CrossRef]

140. Kong, Y.-Y.; Yang, B. The perceived career support, protean career orientation, and subjective career success: Multiple mediating effects of person-job fit and career self-management in the workplace. Int. J. Adv. Sci. Technol. 2019, 28, 174-182.

141. Gerli, F.; Bonesso, S.; Pizzi, C. Boundaryless career and career success: The impact of emotional and social competencies. Front. Psychol. 2015, 6. [CrossRef] [PubMed]

142. Vani, M.; Sankaran, H.; Praveen Kumar, S. The Need for Integrating Emotional Intelligence as an Essential Skill for Graduates with Special Reference to Employability of Engineering Graduates. Int. J. Innov. Technol. Explor. Eng. 2019, 8, 1104-1106. [CrossRef]

143. Frenzel, J.E. Exploration of the entrepreneurial orientation and trait emotional intelligence in practicing pharmacists. J. Am. Pharm. Assoc. 2020, 60, 723-728.e2. [CrossRef] [PubMed]

144. Dan, X.; Xu, S.; Liu, J.; Hou, R.; Liu, Y.; Ma, H. Relationships among structural empowerment, innovative behaviour, self-efficacy, and career success in nursing field in mainland China. Int. J. Nurs. Pract. 2018, 24, e12674. [CrossRef]

145. Drewery, D.W.; Sproule, R.; Pretti, T.J. Lifelong learning mindset and career success: Evidence from the field of accounting and finance. High. Educ. Ski. Work. Learn. 2020, 10, 567-580. [CrossRef]

146. Abdiraiymova, G.; Biekenov, K.; Burkhanova, D.; Serikzhanova, S. The Career Development Experience of Young Academics in Kazakhstan. Russ. Educ. Soc. 2019, 61, 1-16. [CrossRef]

147. Ansaripour, S. The Role of Job Performance on Career Success and Self-esteem of Staff. J. Clin. Diagn. Res. 2017. [CrossRef]

148. Jin, J. The role of assessment centers in job satisfaction and organizational commitment: A case of the Korean government. Int. J. Hum. Resour. Manag. 2018, 29, 1588-1608. [CrossRef]

149. Trolian, T.L.; Jach, E.A.; Archibald, G.C. Shaping Students' Career Attitudes toward Professional Success: Examining the Role of Student-Faculty Interactions. Innov. High. Educ. 2020. [CrossRef]

150. Leroux, J.A.; Lafleur, S. Employability Skills: The demands of the workplace. Vocat. Asp. Educ. 1995, 47, 189-196. [CrossRef]

151. Kiong, T.P.; Yin-Fah, B. C Exploring factors towards career success in Malaysi. Int. Bus. Manag. 2016, 10, 3936-3943.

152. Fragoulis, I.; Phillips, N. Social Skills for Successful Career Development. Rev. Eur. Stud. 2011, 3. [CrossRef]

153. Healy, M.; Hammer, S.; McIlveen, P. Mapping graduate employability and career development in higher education research: A citation network analysis. Stud. High. Educ. 2020, 1-13. [CrossRef]

154. Zhang, X.; Yu, Y.; Zhang, N. Sustainable supply chain management under big data: A bibliometric analysis. J. Enterp. Inf. Manag. 2020. ahead of printing. [CrossRef] 
155. White, H.D.; Griffith, B.C. Author cocitation: A literature measure of intellectual structure. J. Am. Soc. Inf. Sci. 1981, 32, 163-171. [CrossRef]

156. Judge, T.A.; Klinger, R.L.; Simon, L.S. Time is on my side: Time, general mental ability, human capital, and extrinsic career success. J. Appl. Psychol. 2010, 95, 92-107. [CrossRef] [PubMed]

157. Van der Heijden, B.I.J.M.; de Lange, A.H.; Demerouti, E.; Van der Heijde, C.M. Age effects on the employability-career success relationship. J. Vocat. Behav. 2009, 74, 156-164. [CrossRef]

158. Chang, J.; Baek, P.; Kim, T. Women's Developmental Networks and Career Satisfaction: Developmental Functions as a Mediator. J. Career Dev. 2020, 089484531990000. [CrossRef]

159. Hall, D.T.; Lee, M.D.; Kossek, E.E.; Heras, M. Las Pursuing Career Success while Sustaining Personal and Family Well-Being: A Study of Reduced-Load Professionals over Time. J. Soc. Issues 2012, 68, 742-766. [CrossRef]

160. Beigi, M.; Wang, J.; Arthur, M.B. Work-family interface in the context of career success: A qualitative inquiry. Hum. Relat. 2017, 70, 1091-1114. [CrossRef]

161. Eby, L.T.; Durley, J.R.; Evans, S.C.; Ragins, B.R. The relationship between short-term mentoring benefits and long-term mentor outcomes. J. Vocat. Behav. 2006, 69, 424-444. [CrossRef]

162. Jawahar, I.M.; Ferris, G.R. A Longitudinal Investigation of Task and Contextual Performance Influences on Promotability Judgments. Hum. Perform. 2011, 24, 251-269. [CrossRef]

163. Perrewé, P.L.; Nelson, D.L. The Facilitative Role of Political Skill. Organ. Dyn. 2004, 33, 366-378. [CrossRef]

164. Diez-Martin, F.; Blanco-Gonzalez, A.; Prado-Roman, C. Research Challenges in Digital Marketing: Sustainability. Sustainability 2019, 11, 2839. [CrossRef]

165. Dong, D.; Chen, M.-L. Publication trends and co-citation mapping of translation studies between 2000 and 2015. Scientometrics 2015, 105, 1111-1128. [CrossRef]

166. NG, T.W.H.; Feldman, D.C. Human capital and objective indicators of career success: The mediating effects of cognitive ability and conscientiousness. J. Occup. Organ. Psychol. 2010, 83, 207-235. [CrossRef]

167. Kirchmeyer, C. The different effects of family on objective career success across gender: A test of alternative explanations. J. Vocat. Behav. 2006, 68, 323-346. [CrossRef]

168. Wiese, B.S.; Freund, A.M.; Baltes, P.B. Subjective Career Success and Emotional Well-Being: Longitudinal Predictive Power of Selection, Optimization, and Compensation. J. Vocat. Behav. 2002, 60, 321-335. [CrossRef]

169. O'Neil, D.A.; Hopkins, M.M.; Bilimoria, D. Women's Careers at the Start of the 21st Century: Patterns and Paradoxes. J. Bus. Ethics 2008, 80, 727-743. [CrossRef]

170. Bozionelos, N. Mentoring provided: Relation to mentor's career success, personality, and mentoring received. J. Vocat. Behav. 2004, 64, 24-46. [CrossRef]

171. O'Neil, D.A.; Bilimoria, D. Women's career development phases. Career Dev. Int. 2005, 10, 168-189. [CrossRef]

172. Valcour, P.M.; Tolbert, P. Gender, family and career in the era of boundarylessness: Determinants and effects of intra- and inter-organizational mobility. Int. J. Hum. Resour. Manag. 2003, 14, 768-787. [CrossRef]

173. Jolly, S.; Griffith, K.A.; DeCastro, R.; Stewart, A.; Ubel, P.; Jagsi, R. Gender Differences in Time Spent on Parenting and Domestic Responsibilities by High-Achieving Young Physician-Researchers. Ann. Intern. Med. 2014, 160, 344-353. [CrossRef] [PubMed]

174. Ghosh, R.; Reio, T.G. Career benefits associated with mentoring for mentors: A meta-analysis. J. Vocat. Behav. 2013, 83, 106-116. [CrossRef]

175. Chen, M.-H.; Chang, Y.-Y.; Lo, Y.-H. Creativity cognitive style, conflict, and career success for creative entrepreneurs. J. Bus. Res. 2015, 68, 906-910. [CrossRef]

176. Bozionelos, N.; Bozionelos, G.; Kostopoulos, K.; Polychroniou, P. How providing mentoring relates to career success and organizational commitment. Career Dev. Int. 2011, 16, 446-468. [CrossRef]

177. Gibson, D.E. Role models in career development: New directions for theory and research. J. Vocat. Behav. 2004, 65, 134-156. [CrossRef]

178. Mao, N.; Wang, M.-H.; Ho, Y.-S. A Bibliometric Study of the Trend in Articles Related to Risk Assessment Published in Science Citation Index. Hum. Ecol. Risk Assess. An Int. J. 2010, 16, 801-824. [CrossRef]

179. Ellegaard, O.; Wallin, J.A. The bibliometric analysis of scholarly production: How great is the impact? Scientometrics 2015, 105, 1809-1831. [CrossRef]

180. Ahmad, P.; Asif, J.A.; Alam, M.K.; Slots, J. A bibliometric analysis of Periodontology 2000. Periodontology 2000 2020, 82, 286-297. [CrossRef] [PubMed] 